Atmos. Chem. Phys., 13, 10095-10112, 2013

www.atmos-chem-phys.net/13/10095/2013/

doi:10.5194/acp-13-10095-2013

(c) Author(s) 2013. CC Attribution 3.0 License.

\title{
Insights on organic aerosol aging and the influence of coal combustion at a regional receptor site of central eastern China
}

\author{
W. W. Hu ${ }^{1, *}$, M. Hu ${ }^{1, *}$, B. Yuan ${ }^{1, * *}$, J. L. Jimenez ${ }^{3}$, Q. Tang ${ }^{1}$, J. F. Peng ${ }^{1}$, W. Hu ${ }^{1}$, M. Shao ${ }^{1}$, M. Wang ${ }^{1}$, L. M. Zeng ${ }^{1}$, \\ Y. S. Wu ${ }^{1}$, Z. H. Gong ${ }^{1,2}$, X. F. Huang ${ }^{1,2}$, and L. Y. He ${ }^{1,2}$ \\ ${ }^{1}$ State Key Joint Laboratory of Environmental Simulation and Pollution Control, College of Environmental Sciences and \\ Engineering, Peking University, Beijing 100871, China \\ ${ }^{2}$ Key Laboratory for Urban Habitat Environmental Science and Technology, School of Environment and Energy, \\ Peking University Shenzhen Graduate School, Shenzhen 518055, China \\ ${ }^{3}$ Cooperative Institute for Research in the Environmental Sciences (CIRES) and Department of Chemistry and Biochemistry, \\ Univ. of Colorado, Boulder, CO, USA \\ *now at: Cooperative Institute for Research in Environmental Sciences, University of Colorado, Boulder, CO 80309, USA \\ *** now at: Earth System Research Laboratory, Chemical Sciences Division, NOAA, 325 Broadway, Boulder, \\ Colorado 80305, USA
}

Correspondence to: M. Hu (minhu@ pku.edu.cn)

Received: 8 February 2013 - Published in Atmos. Chem. Phys. Discuss.: 24 April 2013

Revised: 18 August 2013 - Accepted: 31 August 2013 - Published: 15 October 2013

\begin{abstract}
In order to understand the aging and processing of organic aerosols (OA), an intensive field campaign (Campaign of Air Pollution at Typical Coastal Areas IN Eastern China, CAPTAIN) was conducted March-April at a receptor site (a Changdao island) in central eastern China. Multiple fast aerosol and gas measurement instruments were used during the campaign, including a high resolution timeof-flight aerosol mass spectrometer (HR-ToF-AMS) that was applied to measure mass concentrations and non-refractory chemical components of submicron particles $\left(\mathrm{PM}_{1}^{\mathrm{nr}}\right)$. The average mass concentration of $\mathrm{PM}_{1}\left(\mathrm{PM}_{1}^{\mathrm{nr}}+\right.$ black carbon $)$ was $47 \pm 36 \mu \mathrm{g} \mathrm{m}^{-3}$ during the campaign and showed distinct variation, depending on back trajectories and their overlap with source regions. Organic aerosol (OA) is the largest component of $\mathrm{PM}_{1}(30 \%)$, followed by nitrate $(28 \%)$, sulfate $(19 \%)$, ammonium (15\%), black carbon (6\%), and chloride (3\%). Four OA components were resolved by positive matrix factorization (PMF) of the high-resolution spectra, including low-volatility oxygenated organic aerosol (LV-OOA), semivolatile oxygenated OA (SV-OOA), hydrocarbon-like OA (HOA) and a coal combustion OA (CCOA). The mass spectrum of CCOA had high abundance of fragments from polycyclic aromatic hydrocarbons (PAHs) $(m / z 128,152,178$, etc.). The average atomic ratio of oxygen to carbon in $\mathrm{OA}$
\end{abstract}

$(\mathrm{O} / \mathrm{C})$ at Changdao was 0.59 , which is comparable to other field studies reported at locations downwind of large pollution sources, indicating the oxidized nature of most OA during the campaign. The evolution of OA elemental composition in the van Krevelen diagram $(\mathrm{H} / \mathrm{C}$ vs. $\mathrm{O} / \mathrm{C})$ showed a slope of -0.63 ; however, the OA influenced by coal combustion exhibits a completely different evolution that appears dominated by physical mixing. The aging of organic aerosols vs. photochemical age was investigated. It was shown that $\mathrm{OA} / \Delta \mathrm{CO}$, as well as LV-OOA / $\Delta \mathrm{CO}$ and SV-OOA / $\Delta \mathrm{CO}$, positively correlated with photochemical age. LV-OOA accounted for $73 \%$ of the OA secondary formation (SOA) in the oldest plumes (photochemical age of $25 \mathrm{~h}$ ). The $k_{\mathrm{OH}}$ at Changdao, by assuming SOA formation and aging as a first-order process proportional to $\mathrm{OH}$, was calculated to be $5.2 \times 10^{-12} \mathrm{~cm}^{3}$ molec. ${ }^{-1} \mathrm{~s}^{-1}$, which is similar to those determined in recent studies of polluted air in other continents. 


\section{Introduction}

The primary sources and secondary formation of fine particles are key issues in the quantification of aerosol effects on regional air quality, climate change and human health. A major uncertainty at present are the sources, fate and aging of organic aerosols (OA), which are still not well understood due to their extremely complex composition, properties, and reaction pathways. This is especially true for the secondary organic aerosols (SOA) formed from chemical reactions of gas-phase species (Hallquist et al., 2009). Tackling this challenge requires application and improvement of advanced instrumentation and data analysis techniques.

The recently developed high-resolution time-of-flight aerosol mass spectrometer (HR-ToF-AMS) has been widely used to investigate the properties and dynamic evolution of organic aerosol, thanks to its fast response (seconds to minutes), low detection limits (typically $<0.2 \mu \mathrm{g} \mathrm{m}^{-3}$ in $2 \mathrm{~min}$ for $\mathrm{OA}$ ) and ability to provide some composition information on the bulk OA. By analyzing the high mass resolution AMS spectra with a factor analysis technique (e.g., positive matrix factorization, PMF), OA measured by AMS can often be apportioned to several components, including hydrocarbonlike organic aerosol (HOA), regarded as a surrogate of anthropogenic primary organic aerosol (POA), and oxygenated organic aerosol (OOA), typically a surrogate for SOA (Zhang et al., 2005a). Other POA components have been reported at some locations such as biomass burning OA (Aiken et al., 2010) and cooking OA (Huang et al., 2010; Hayes et al., 2013). OOA factors with different oxidation states were recognized, with low volatility OOA (LV-OOA) typically representing aged SOA and semi-volatile OOA (SV-OOA) representing freshly formed SOA (Huang et al., 2010; Sun et al., 2011; Ulbrich et al., 2009). Bulk OA evolution from HOA dominance to SV-OOA and then to LV-OOA dominance have been observed in laboratory studies and the ambient measurements (Jimenez et al., 2009).

Large gaps between modeled and measured SOA have been reported in many polluted areas (Volkamer et al., 2006; Heald et al., 2011). Many hypotheses have been proposed to explain the model-measurement differences, including higher SOA yields from the anthropogenic precursors at both high- $\mathrm{NO}_{\mathrm{x}}$ and low- $\mathrm{NO}_{\mathrm{x}}$ conditions ( $\mathrm{Ng}$ et al., 2007); formation of SOA in the aerosol water phase by soluble volatile organics (Volkamer et al., 2007); and gas/particle partitioning and oxidation of previously ignored semivolatile/intermediate volatile organic compounds (SVOCs/IVOCs) (Robinson et al., 2007). However, while the net effect of SOA formation and aging processes in polluted areas is better constrained (Hodzic and Jimenez, 2011; Hu et al., 2012), the actual pathways responsible for the observed SOA are still unclear (Hodzic et al., 2010; Dzepina et al., 2011; Ervens et al., 2011). Elemental ratios (O/C and H/C) of organic aerosols have been shown to be useful bulk properties to probe $\mathrm{OA}$ sources and evolution without considering detailed molecular structures (Aiken et al., 2008; Jimenez et al., 2009). In recent studies, $\mathrm{O} / \mathrm{C}$ has been used as an independent variable in the two-dimension volatility basis set (VBS) model as a constrained parameter in order to improve predictions of thermodynamic properties of SOA (including organic mixing, polarity and oxidation chemistry, etc.) (Donahue et al., 2011).

Multiple results based on satellite (Velders et al., 2001), field (Zhang et al., 2007), and modeling studies (Spracklen et al., 2011) revealed that central eastern China (includes two of the biggest megacity clusters of China: Beijing-Tianjin area and Yangzi River delta area) has severe air pollution problems associated with high population and activity density. Average concentration of fine particles in Beijing, the largest megacity in central eastern China, was found to be among the highest in the world and its value even twice higher than that in Mexico City (Zhang et al., 2007). Primary sources such as coal combustion and traffic emissions are recognized as important contributors mostly to fine particles in the winter of central eastern China, and SOA formation dominated the fine particle mass in the summertime (Wang et al., 2009).

An intensive field campaign was conducted at a regional receptor site in central eastern China. A high-resolution timeof-flight aerosol mass spectrometer (HR-ToF-AMS) coupled with other instruments were deployed at the site. This study had four main objectives: (1) an overview of time series, chemical composition and size distributions of submicron particles in the continental outflow of central eastern China; (2) a study of OA primary and secondary components using positive matrix factorization (PMF) of high-resolution AMS data; (3) an analysis of bulk elemental composition $(\mathrm{O} / \mathrm{C}$, $\mathrm{H} / \mathrm{C}$ and N/C) of OA; and (4) the evolution of OA, PMF components, and $\mathrm{OA}$ elemental ratios with photochemical age.

\section{Measurements}

\subsection{Sampling site}

The sampling site was part of the intensive field campaigns (Campaign of Air Pollution at Typical Coastal Areas IN Eastern China, CAPTAIN) conducted in the spring from 21 March to 24 April 2011 at an island of Changdao $\left(37.99^{\circ} \mathrm{N}\right.$, $\left.120.70^{\circ} \mathrm{E}\right)$. This Changdao island $\left(22 \mathrm{~km}^{2}\right)$ is located offshore to the east edge of central eastern China and lies between the Jiaodong and the Liaodong Peninsula in the Bohai Sea (see Fig. S1 in the Supplement), and can be classified as a location downwind of major pollution sources from central eastern China. The sampling site was located on the north coast on a hill at $\sim 50 \mathrm{~m}$ a.s.l. The observation site island is surrounded by sea on three sides and connected with a larger island by a bridge on the south side. 


\subsection{HR-ToF-AMS operation}

The mass concentrations and size distributions of submicron non-refractory species $\left(\mathrm{PM}_{1}^{\mathrm{nr}}\right)$ including organic aerosol (OA) and inorganic aerosols (sulfate, nitrate, ammonium, chloride) were measured by HR-ToF-AMS (Aerodyne Research, Inc.). The high mass resolution of the HR-ToF-AMS has a greatly improved ability to identify and quantify ions at the same integer $m / z$ (DeCarlo et al., 2006). For the sake of simplicity, we will refer to this instrument as AMS in the following discussion.

Ambient air was sampled through a $\mathrm{PM}_{2.5}$ cyclone to remove coarse particles, which was set on the roof of the sampling room, then the air passed through a $3 / 8$ inch $(\sim 9.5 \mathrm{~mm})$ copper tube (about $3 \mathrm{~m}$ long) at a flow rate of $10 \mathrm{~L} \mathrm{~min}^{-1}$. Air subsampled isokinetically into the AMS from the center of the copper tube at a flow rate of $\sim 0.09 \mathrm{~L} \mathrm{~min}^{-1}$. A nafion dryer (Perma Pure, Inc.) was used to dry the sampled air stream, which kept relative humidity $(\mathrm{RH})$ of air below $30 \%$ within the AMS.

During the campaign, the AMS was alternated between $\mathrm{V}$ mode and $\mathrm{W}$ mode every $2 \mathrm{~min}$. In $\mathrm{V}$ mode the instrument alternated in steps of $10 \mathrm{~s}$ between mass spectrum (MS) mode for total submicron mass concentrations and mass spectra, and $10 \mathrm{~s}$ in particle time-of-flight (PToF) mode to measure chemically-speciated particle size distributions. In $\mathrm{W}$ mode only MS mode was used. Ionization efficiency (IE) calibrations were conducted every 5-7 days during the entire campaign (7 times in total), using size-selected $400 \mathrm{~nm}$ pure ammonium nitrate particles. The ratios of IE to $\mathrm{N}_{2}^{+}$"airbeam" signal (AB) were very stable for the whole campaign, with variations less than $10 \%$. Flow rate and sizing calibrations were carried out before and after the campaign. The lens pressure for the sizing calibrations was within $15 \%$ of those during the field study. Monodisperse polystyrene latex spheres (PSLs, density $=1.05 \mathrm{~g} \mathrm{~cm}^{-3}$ ) (Duke Scientific, Palo Alto, CA, US) with nominal standard diameters of 100$900 \mathrm{~nm}$, as well as SMPS selected $50-600 \mathrm{~nm}$ pure particles of ammonium nitrate, were introduced into the AMS as sizing standards. The $\mathrm{m} / \mathrm{z}$ calibration and the baseline and threshold parameters of the data acquisition board were checked every 2-3 days, and were very stable.

Detection limits (DLs) of species measured by AMS were determined as 3 times the standard deviations of mass concentrations in particle-free air through a high efficiency particulate air (HEPA) filter (Zhang et al., 2005a; DeCarlo et al., 2006). The DLs of AMS for different species during the Changdao campaign are listed in Table 1, and were much lower than typical measured concentrations, providing high signal-to-noise measurements. As expected, the DLs in $\mathrm{W}$ mode were slightly higher than the values of $\mathrm{V}$ mode for organics and nearly twice for the inorganics.
Table 1. The detection limits $\left(\mathrm{ng} \mathrm{m}^{-3}\right)$ of species measured by AMS in $\mathrm{V}$ mode and in $\mathrm{W}$ mode.

\begin{tabular}{lccccc}
\hline Mode & Sulfate & Nitrate & Ammonium & Chloride & Organics \\
\hline V & 34 & 15 & 37 & 53 & 120 \\
W & 47 & 31 & 64 & 93 & 140 \\
\hline
\end{tabular}

\subsection{AMS data analysis}

The concentrations and size distributions of $\mathrm{PM}_{1}^{\mathrm{nr}}$ species from $\mathrm{V}$ mode were obtained after analysis with the standard ToF-AMS data analysis software packages (SQUIRREL version $1.51 \mathrm{H}$ and PIKA version 1.1). High resolution mass spectra from $\mathrm{W}$ mode were also extracted. The default userdefined fragmentation table was applied to the Changdao AMS data analysis, with some adjustments based on standard procedures for $m / z$ 's $15,16,29,44$, etc. The default relative ionization efficiency (RIE) values were used for this campaign, except for ammonium for which $\mathrm{RIE}=5.0$ was used based on the IE calibrations.

A particle collection efficiency (CE) is needed to account for particle bounce losses on the AMS vaporizer $\left(E_{\mathrm{b}}\right)$ as a function of particle size (Canagaratna et al., 2007). Extensive inter-comparisons across many field studies have shown that $\mathrm{CE}=0.5$ is the correct value at most field locations (Aiken et al., 2009; Canagaratna et al., 2007; Sun et al., 2011; Zhang et al., 2005a). After using $\mathrm{CE}=0.5$ to calculate AMS mass concentrations, the AMS performance and quantification in this study were evaluated with inter-comparisons between AMS and collocated instruments. Good correlation between AMS and on-line EC/OC analyzer for organic aerosols $(R=0.81)$, as well as AMS and GAC-IC for inorganic aerosols $(R=0.88-0.95)$, were found (Figs. S3-S4). The $\mathrm{PM}_{1}$ concentration from AMS species $+\mathrm{BC}$ are also very similar to the integrated particle mass concentrations (15$600 \mathrm{~nm}$ ) from SMPS, with a correlation coefficient of 0.92 and a slope of 0.96 (Fig. S5). The general mass concentrations trends of different aerosol species are reproduced by each pair of instruments, which validates the reliability of AMS results measured.

In some cases, $\mathrm{CE}$ of ambient particles can reach higher values for high humidity inlet conditions, strongly acidic sulfate aerosols, and high ammonium nitrate content (Middlebrook et al., 2011). Since the sampled air into AMS was dried, most of the aerosols were neutralized (see Fig. S2 in the Supplement), and as the good comparison results between AMS and collocated measurements (GAC and SMPS) were satisfactory (Figs. S3-S5), a CE of 0.5 was finally used in the Changdao campaign.

Compared with the lower mass resolution spectra from $\mathrm{V}$ mode, the HR mass spectra from $\mathrm{W}$ mode provides a better separation of different organic components in positive matrix factor (PMF) analysis, especially for datasets such as this 
study with high concentrations and thus good signal-to-noise in $\mathrm{W}$ mode spectra. The OA mass spectral matrix over the $m / z$ range 12-196 was utilized in the PMF analysis. PMF analysis procedures for AMS datasets have been described by Ulbrich et al. (2009) and Zhang et al. (2011). Detailed information about PMF results and selection of the best solution is presented in Part 6 of the Supplement.

\subsection{Other instruments}

During the campaign, there were many collocated fast response aerosol and gas measurement instruments besides the AMS. Those whose data are used in the paper are briefly introduced below.

Black carbon (BC) was measured by aethalometer (Magee Scientific) with a time-resolution of $2 \mathrm{~min}$ and a $\mathrm{PM}_{2.5}$ size cut. The particle number size distribution between $15-$ $600 \mathrm{~nm}$ was measured with a scanning mobility particle sizer (SMPS, TSI Incorporated). A custom-built gas and aerosol collector (GAC) combined with ion chromatography (IC) was used to measure water soluble inorganic components in $\mathrm{PM}_{2.5}$ (sulfate, nitrate, chloride, ammonium sodium). The time-resolution of GAC-IC is $30 \mathrm{~min}$. Detailed information on performance and calibration of the GAC-IC has been presented elsewhere (Dong et al., 2012).

A commercial proton transfer reaction-mass spectrometer (PTR-MS, Ionicon) with a time resolution of $30 \mathrm{~s}$, and a custom-built on-line GC-MS/FID with a time-resolution of $1 \mathrm{~h}$ were used to measure multiple volatile organic compounds (VOCs) (Yuan et al., 2010). Concentrations of naphthalene, acetonitrile, benzene, toluene and acetaldehyde from PTR-MS and ethylbenzene and $m+p$-xylene from GCMS/FID were used in this study. Concentrations of $\mathrm{CO}$ and $\mathrm{O}_{3}$ were measured by an enhanced trace level $\mathrm{CO}$ analyzer (48C, Thermo Environmental Instruments Inc. (TEI), US) and an UV absorption ozone analyzer (49C, Thermo Environmental Instruments Inc. (TEI), US) with an integration time of 1 min. A summary of instrument parameters is presented in Table S1.

\section{Results and discussion}

\subsection{Time series, chemical compositions and size distributions of $\mathbf{P M}_{1}$}

In order to focus on the regional contribution to fine particle concentrations at Changdao, periods strongly influenced by local coal combustion and biomass burning were excluded by recognizing concentration peaks of their corresponding indicators, naphthalene and acetonitrile, respectively. A detailed description of the period selection filtering processes can be obtained in Part 4 of the Supplement. Time series for $\mathrm{PM}_{1}$ species during the whole campaign are shown in Fig. 1, together with variations of meteorological parameters. The mass concentration of $\mathrm{PM}_{1}$ species varied drastically be-

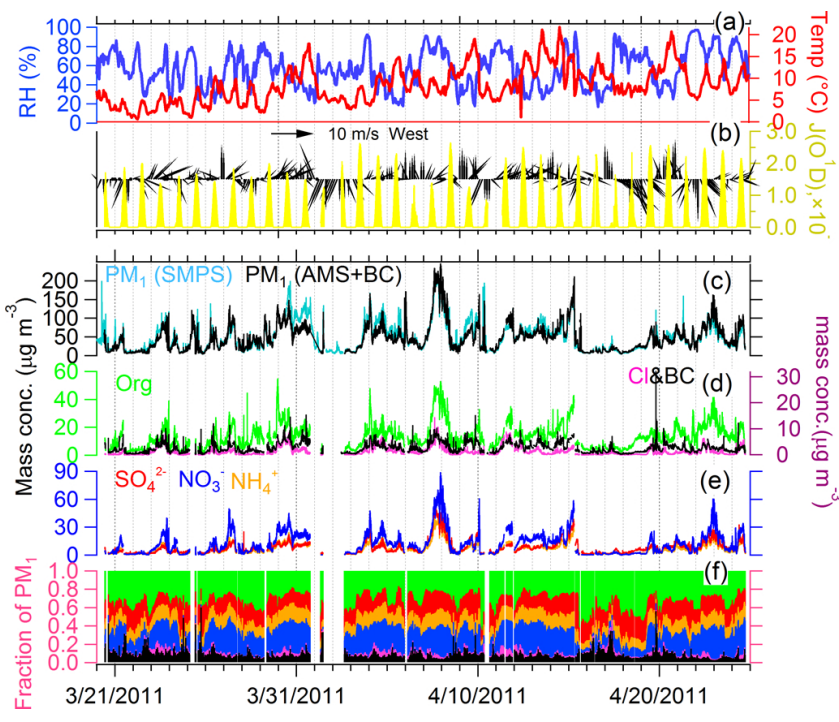

Fig. 1. Time series of (a) relative humidity (RH) and temperature (Temp) at the Changdao site; (b) Time series of local wind direction and speed (left axis) as well as $J\left(\mathrm{O}^{1} \mathrm{D}\right)$ values (right axis); (c) Time series of $\mathrm{PM}_{1}$ concentrations calculated from SMPS volume concentrations $(15-600 \mathrm{~nm})$ and from AMS species+BC. Temporal particle density calculated by the main chemical composition of particle measured by AMS and is applied to the calculation of $\mathrm{PM}_{1}$ mass concentrations from SMPS. The density varied from 1.3-1.6 with an average value of $1.5 \mathrm{~g} \mathrm{~cm}^{-3}$. (d) Time series of organics (left), chloride and BC (right). (e) Time series of sulfate, nitrate, and ammonium. (f) The fractions of AMS species and $\mathrm{BC}$ in $\mathrm{PM}_{1}$ concentrations.

tween different periods and was very sensitive to transport directions of plumes. High concentrations were observed when air masses came from south or southwest areas with high emission density of air pollutants. The highest $\mathrm{PM}_{1}$ concentration observed from southwest was $240 \mu \mathrm{g} \mathrm{m}^{-3}$. Clean episodes typically occurred when transport of plumes from the north dominated, with an average $\mathrm{PM}_{1}$ concentration of $8.8 \pm 1.8 \mu \mathrm{g} \mathrm{m}^{-3}$.

The statistics of concentrations of the chemical species in $\mathrm{PM}_{1}$ are summarized in Table 2 . The average $\mathrm{PM}_{1}$ concentration at the Changdao site is $47 \pm 36 \mu \mathrm{g} \mathrm{m}^{-3}\left(\mathrm{PM}_{1}^{\mathrm{nr}}\right.$ : $42 \mu \mathrm{g} \mathrm{m}^{-3}$ ), which is similar to values measured at other downwind sites in China (35-41 $\mu \mathrm{g} \mathrm{m}^{-3}$ ) (Huang et al., 2011; Xiao et al., 2011) and is lower than the concentrations in Beijing (2006 summer, $71 \mu \mathrm{g} \mathrm{m}^{-3}$, Sun et al., 2010; 2008 summer, $61 \mu \mathrm{g} \mathrm{m}^{-3}$, Huang et al., 2010), which is located upwind of Changdao. Other AMS results obtained at different surface sites in the mid-latitudes of the Northern Hemisphere are shown in Fig. S7 (Zhang et al., 2007). It shows that the average $\mathrm{PM}_{1}$ concentration at Changdao is about 2-4 times higher than the values measured at downwind sites in other regions, and higher than the concentrations measured at urban cities in the US and European countries (de Gouw et al., 2005; Jimenez et al., 2009). These comparisons emphasize 
Table 2. Summary of the mass concentrations of $\mathrm{PM}_{1}$ species and OA components (unit: $\mu \mathrm{g} \mathrm{m}^{-3}$; time resolution is $4 \mathrm{~min}$ ). The stronger influences from local biomass burning and coal combustion are excluded from the dataset.

\begin{tabular}{lrrrrr}
\hline & Average & Std. Dev. & Median & Minimum & Maximum \\
\hline Organics & 13.4 & 8.4 & 12.3 & 1.50 & 54.4 \\
LV-OOA & 6.1 & 4.4 & 4.9 & 0.12 & 25.5 \\
SV-OOA & 3.3 & 4.1 & 1.8 & 0.00 & 27.5 \\
HOA & 3.2 & 2.7 & 2.5 & 0.01 & 28.9 \\
CCOA & 1.2 & 1.4 & 0.9 & 0.00 & 15.0 \\
\hline Sulfate & 8.3 & 7.3 & 6.5 & 0.10 & 59.8 \\
Nitrate & 12.2 & 12.0 & 9.3 & $<$ DLs & 88.7 \\
Ammonium & 6.5 & 6.0 & 5.0 & 0.01 & 41.2 \\
Chloride & 1.3 & 1.6 & 0.7 & $<$ DLs & 14.4 \\
BC & 2.5 & 1.8 & 2.1 & 0.10 & 32.0 \\
PM & 46.6 & 36.5 & 39.4 & 4.40 & 245.0 \\
\hline
\end{tabular}

the heavily polluted conditions for fine PM in central eastern China.

Organic aerosol (OA) is the most abundant species in $\mathrm{PM}_{1}$, accounting for $30 \%$ of total mass (Fig. 2a), followed by nitrate $(28 \%)$, sulfate $(19 \%)$, ammonium $(15 \%)$, BC $(6 \%)$ and chloride $(3 \%)$. The relative contribution of each species to $\mathrm{PM}_{1}$ mass as a function of the total $\mathrm{PM}_{1}$ mass is shown in Fig. 2c, together with a probability density distribution of the $\mathrm{PM}_{1}$ mass. When $\mathrm{PM}_{1}$ concentrations are below $10 \mu \mathrm{g} \mathrm{m}^{-3}$, OA comprises about half of $\mathrm{PM}_{1}$ mass, followed by sulfate $(\sim 26 \%)$, and nitrate $(8 \%)$. Nitrate is the main contributor to the increases of $\mathrm{PM}_{1}$ concentration when $\mathrm{PM}_{1}$ concentrations are larger than $10 \mu \mathrm{g} \mathrm{m}^{-3}$. The high fractions of nitrate are found to be positively correlated with higher $\mathrm{RH}$ $(>65 \%)$ and abundant nitrate precursors $\left(\mathrm{NO}_{\mathrm{x}}\right)$ from inland. In contrast to nitrate, sulfate maintains a pretty stable fraction $(\sim 20 \%)$ during the whole campaign. As $\mathrm{PM}_{1}$ concentrations become larger, the fraction of $\mathrm{BC}$ decreases from 8 to $3 \%$, whereas the fractions of chloride increase slowly from 1 to $3 \%$, implying the difference emission sources of the two species.

The observed total water soluble chlorides (including chlorides from sea salts) to Na ratio from GAC-ICs system is $3.8 \pm 2.6$, which is much higher than the ratio (1.8) from fresh sea salt, indicating that over half of the fine chloride at Changdao may also be emitted by anthropogenic sources. If we assume chloride detected by AMS approximately corresponds to total non-sea salt chloride, the ratio between chloride measured by AMS $\left(1.3 \mu \mathrm{g} \mathrm{m}^{-3}\right)$ and GACICs $\left(2.1 \mu \mathrm{g} \mathrm{m}^{-3}\right)$ suggests that at least $57 \%$ of total water soluble chlorides at Changdao are from anthropogenic sources, which is consistent with the above estimate.

The average vacuum aerodynamic $\left(d_{\mathrm{va}}\right)$ size distributions of AMS species are shown in Fig. 2b, together with the integrated mass size distributions from SMPS. Secondary inorganic aerosols (nitrate, sulfate and ammonium) show similar size distribution shapes and have peaks at around 500-
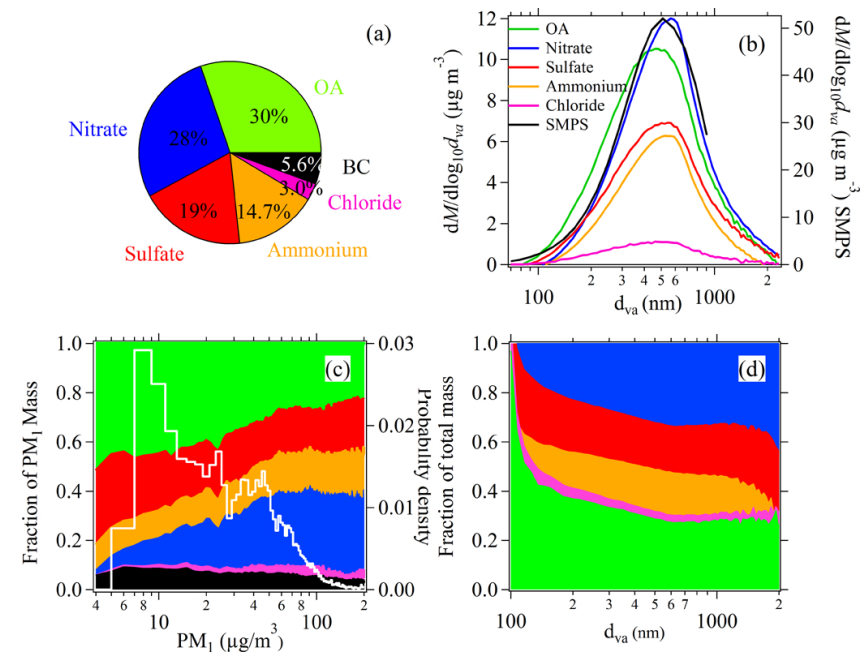

Fig. 2. (a) The average chemical compositions of $\mathrm{PM}_{1}$ during the campaign. (b) Average size-resolved distributions of AMS species and $\mathrm{PM}_{1}$ calculated from SMPS. (c) The fractions of main chemical components in $\mathrm{PM}_{1}$ as a function of $\mathrm{PM}_{1}$ concentrations (left). Probability density of $\mathrm{PM}_{1}$ concentrations (right). (d) The fractions of AMS species in total $\mathrm{PM}_{1}$ as a function of vacuum aerodynamic size $\left(d_{\mathrm{va}}\right)$. The volume concentration and the mobility diameter measured by the SMPS was converted into vacuum aerodynamic size by a scale factor of 1.5 (approximate density) in both cases.

$600 \mathrm{~nm}$, indicating the internally mixed conditions of secondary inorganics. The peak in size distribution $(\sim 450 \mathrm{~nm})$ of $\mathrm{OA}$ is smaller than those of secondary inorganics, and it shows a broader size distribution with mass enhancements at small sizes $(100-200 \mathrm{~nm})$, similar to results reported in other regions (Aiken et al., 2009; Huang et al., 2010; Zhang et al., 2005b). The small size mode of OA is probably associated with primary emissions from vehicle or coal burning or other primary sources (Canagaratna et al., 2004; Huang et al., 2010). OA account for $\sim 40 \%$ of $\mathrm{PM}_{1}^{\mathrm{nr}}$ mass within the $d_{\text {va }}$ range $100-200 \mathrm{~nm}$, and that fraction is reduced to $28 \%$ (Fig. 2d) at larger sizes. The fraction of nitrate is larger at higher $d_{\mathrm{va}}$. Sulfate displays a constant fraction of $\mathrm{PM}_{1}^{\mathrm{nr}}$ with increasing size $(\sim 20 \%)$, implying sulfate uniformly mixes with aerosols in a regional scope.

\subsection{Investigating OA sources with PMF}

Four OA components were identified from AMS spectra with distinct mass spectral profiles and temporal variations: hydrocarbon-like OA (HOA, mostly from primary emissions); semi-volatile oxygenated OA (SV-OOA), which is a surrogate of fresher SOA; low-volatility oxygenated OA (LVOOA) for a surrogate of aged SOA (Jimenez et al., 2009); and a coal combustion OA (CCOA). The CCOA in high resolution spectra is reported here for the first time to our knowledge. The diagnostic plots and detailed descriptions of the 


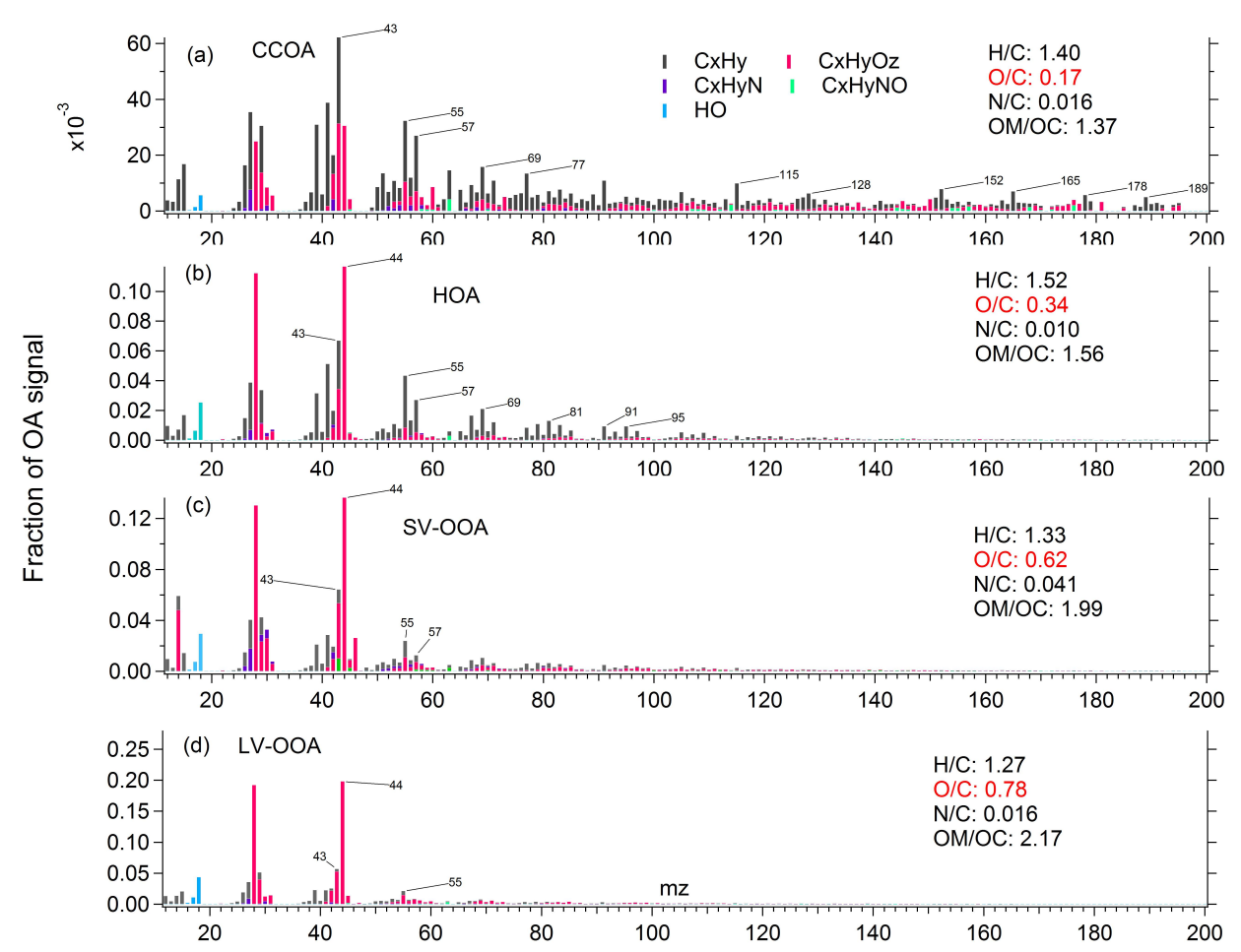

Fig. 3. High resolution mass spectra of OA components (a) coal combustion OA (CCOA); (b) hydrocarbon-like OA (HOA); (c) semi-volatile oxygenated OA (SV-OOA); (d) low-volatile oxygenated OA (LV-OOA). The elemental ratios and OM/OC ratios of each component are also shown in the legends.

PMF analysis can be found in Part 6 of the Supplement. Detailed discussion of each OA component is below.

\subsubsection{Hydrocarbon-like OA (HOA)}

The mass spectra of HOA is dominated by alkyl fragments $\left(\mathrm{C}_{n} \mathrm{H}_{2 n+1}^{+}: m / z 29,43,57,71,85,99 \ldots\right.$ and $\mathrm{C}_{n} \mathrm{H}_{2 n-1}^{+}: m / z$ $27,41,55,69,83,97 \ldots$ ) as shown in Fig. 3, similar to previously reported reference spectra of HOA (Aiken et al., 2009; Huang et al., 2010; $\mathrm{Ng}$ et al., 2011b). The O/C ratio of HOA at Changdao is pretty high (0.34), which is higher than the values $(0.03-0.17)$ reported elsewhere, and was in the range of O/C ratios ( 0.24-0.42) from biomass burning (DeCarlo et al., 2010; Huang et al., 2010; Jimenez et al., 2009). The high $\mathrm{O} / \mathrm{C}$ ratio in $\mathrm{HOA}$ is caused by the high abundances of oxidized fragment ions $\left(\mathrm{CO}_{2}^{+}\right.$and $\left.\mathrm{CO}^{+}\right)$, indicating the HOA resolved at Changdao site is relatively oxidized. $\mathrm{CO}_{2}^{+}$ and $\mathrm{CO}^{+}$ions contribute a total $60 \%$ of the $\mathrm{O}$ ratios in HOA. Although HOA shows a certain degree of oxidization, good correlations between HOA and primary emission species $\left(\mathrm{NO}_{\mathrm{x}}\right.$, benzene and $\left.\mathrm{BC}\right)$ (Table $\left.\mathrm{S} 2\right)$ strongly suggest that $\mathrm{HOA}$ arises from primary emission sources. The specific alkyl fragment ions $\left(\mathrm{C}_{3} \mathrm{H}_{7}^{+}\right.$and $\left.\mathrm{C}_{4} \mathrm{H}_{9}^{+}\right)$from $m / z 55$ and 57 are often used as tracers of primary sources (Aiken et al., 2009). In this study, about $45 \%$ and $55 \%$ of the signal at $\mathrm{C}_{3} \mathrm{H}_{7}^{+}$and $\mathrm{C}_{4} \mathrm{H}_{9}^{+}$are contributed by HOA (Fig. 7). For the whole campaign, HOA accounts for $23 \%$ of total OA mass on average, and shows the highest contribution $(28 \%)$ in the morning (07:00-08:00 LT) and the lowest (19\%) in the afternoon (Fig. 6b).

\subsubsection{Coal combustion OA (CCOA)}

Coal combustion accounts for about $25 \%$ of the total world energy consumption and is expected to have an annual global consumption of 10.6 billion tons in 2030 with a current annual increase of $2-3 \%$ (Zhang et al., 2008). Coal combustion has not been reported to be an important source of OA in the US or Europe (Jacobson, 2002), consistent with our understanding that combustion of coal in well-functioning pulverized coal-combustion power plants with emission controls is very low. However, combustion of coal at small scale (e.g., for domestic use) may be an important OA source, and in recent years there have been more concerns about OA emissions from coal combustion due to their important impacts on climate changes and health effects (Jacobson, 2002; Zhang et al., 2008). A PMF organic factor from coal combustion at Changdao is resolved and reported here. Although there are several AMS studies exhibiting the mass profiles of organic aerosols resolved from specific combustion sources, e.g., wood burning (Aiken et al., 2009; Huang et al., 2011; Lanz et al., 2008) or mixed solid fuel combustion sources from wood, coal (28\%), peat (14\%) and smokeless fuels (4\%) (Allan et al., 2010), a factor associated with coal 
combustion OA (CCOA) is characterized and reported in this study for the first time to our knowledge.

Although strong coal combustion influences (spikes in time series of organic aerosols) at the Changdao site are already excluded (Part 4 in the Supplement), less intense local emissions and emissions of coal combustion in the regional scale can also influence the Changdao site. The mass spectrum of CCOA is dominated by alkyl fragments $\left(\mathrm{C}_{n} \mathrm{H}_{2 n+1}^{+}\right.$ and $\mathrm{C}_{n} \mathrm{H}_{2 n-1}^{+}$), which is typical of primary organic aerosols from fossil fuel combustion. The $\mathrm{H} / \mathrm{C}$ and $\mathrm{O} / \mathrm{C}$ ratios in CCOA are 1.40 and 0.17 , both of which are lower than the ratios in HOA (1.52 and 0.34). The high abundances of PAHs $(\mathrm{H} / \mathrm{C}$ ratios $<1)$ in CCOA may be the possible reason for the lower $\mathrm{H} / \mathrm{C}$ ratio in CCOA. PAH ion fragments, such as $\mathrm{m} / \mathrm{z}$ 128, 152, 178, 189, 202 and 216, etc. (Dzepina et al., 2007), are easily observed in the mass spectrum of CCOA (Fig. 3). The PAH concentrations can account for $\sim 38 \%$ of total organic mass in coal combustion plumes (Zhang et al., 2008). Unfortunately, the $m / z$ range measured in $\mathrm{W}$ mode in this study was limited to $m / z, 12-196$, and PAH ion fragments above $m / z 196$ cannot be reflected in the PMF results here. However, since other PMF factors are dominated by ions below $m / z$ 100, the PAH ion fragments ranging from 100 to 189 are clear enough to reflect this unique feature of CCOA.

Two periods influenced by local coal combustion at Changdao corresponding to different high naphthalene concentrations (partially- and strongly-influenced by coal combustion periods are referred to as naphthalene concentrations above $1.5 \mathrm{ppb}$ and $3.0 \mathrm{ppb}$, respectively) were identified by the concentrations of gas-phase naphthalene from PTR-MS. The mass spectra of coal plumes during these two periods (that were not included in the PMF analysis) were averaged by subtracting background of spectrum before and after the plumes. Those two mass spectra are used to compare with the spectrum of CCOA. The average mass spectrum from partially-influenced coal combustion ( $\left.\mathrm{MS}_{\text {partial-coal }}\right)$ shows substantial enhancement of masses with $\mathrm{m} / z>100$, especially for PAH parent and fragment ions (Fig. 4a). The O/C and $\mathrm{OM} / \mathrm{OC}$ ratio (0.18 and 1.37) in $\mathrm{MS}_{\text {partial-coal }}$ is comparable to the value in mass spectrum of CCOA $\left(\mathrm{MS}_{\mathrm{CCOA}}\right)$ ( 0.17 and 1.33). The average spectrum in the plumes of strong coal combustion $\left(\mathrm{MS}_{\text {strong-coal, }}\right.$ as Fig. 4b shows) shows much obviously higher enhancements of PAH fragment ions, compared to the $\mathrm{MS}_{\mathrm{CCOA}}$ and $\mathrm{MS}_{\text {partial-coal }}$. Also, it is notable that the $\mathrm{H} / \mathrm{C}$ in the $\mathrm{MS}_{\text {strong-coal }}$ is pretty low (1.1), consistent with $\mathrm{H} / \mathrm{C}$ ratios for PAHs species. The $\mathrm{O} / \mathrm{C}$ and $\mathrm{OM} / \mathrm{OC}$ ratios in $\mathrm{MS}_{\text {strong-coal }}$ are respectively 0.11 and 1.25 , which are lower than the ratios in the $\mathrm{MS}_{\mathrm{CCOA}}(0.17$ and 1.33). Biomass burning has also been reported as an important source of particle-phase PAHs under some conditions (Poulain et al., 2011; Weimer et al., 2008). However, during the Changdao campaign, no enhancement of PAH fragments ions were observed in the mass spectra of biomass burning emissions, as shown in Fig. 4c.
The time series of CCOA in Fig. 5 shows a similar trend ( $R=0.62$ ) to the gas-phase PAH naphthalene. CCOA also has positive correlation with primary single-ring aromatic VOCs species (benzene and toluene) with correlation coefficients of 0.63 and 0.60 , respectively. The diurnal variation pattern of CCOA displays a pronounced peak at 07:00 LT. (Fig. 6a), and later decreases due to the growth of the boundary layer, with a minimum value around 16:00 LT. The average CCOA fraction of total OA is about $9 \%$ (Fig. 6d). However, since we exclude some OA data corresponding to the periods most strongly influenced by coal combustion, the contributions of coal combustion to organic aerosol concentrations should be larger than the value reported here.

The contributions of specific ions to two important $\mathrm{m} / \mathrm{z}$ (128 and 152) in CCOA are shown in Fig. 7. $\mathrm{C}_{10} \mathrm{H}_{8}^{+}$(molecular ion of naphthalene) and $\mathrm{C}_{12} \mathrm{H}_{8}^{+}$PAHs constitute $80 \%$ and $79 \%$ of the unit mass signal at $m / z 128$ and 152 , respectively (Fig. 7). Some other oxygenated ions account for the remaining signal at $m / z 128\left(\mathrm{C}_{6} \mathrm{H}_{8} \mathrm{O}_{3}^{+}\right.$and $\left.\mathrm{C}_{7} \mathrm{H}_{12} \mathrm{O}_{2}^{+}\right)$and $m / z 152\left(\mathrm{C}_{7} \mathrm{H}_{6} \mathrm{NO}_{3}^{+}\right.$and $\left.\mathrm{C}_{9} \mathrm{H}_{12} \mathrm{O}_{2}^{+}\right) . m / z 178$ is dominated by $\mathrm{C}_{14} \mathrm{H}_{10}^{+}$ion. CCOA accounts for about $35-70 \%$ of the PAH fragment ions $\left(\mathrm{C}_{10} \mathrm{H}_{8}^{+}, \mathrm{C}_{12} \mathrm{H}_{8}^{+}\right.$and $\left.\mathrm{C}_{14} \mathrm{H}_{10}^{+}\right)$with larger fractions in heavier ions.

\subsubsection{Semi-volatile $O A$ and low-volatility oxygenated OA (SV-OOA and LV-OOA)}

SV-OOA and LV-OOA were resolved by the PMF 4-factors solution. The mass spectra of LV-OOA and SV-OOA are dominated by the oxygenated fragment ions $\left(\mathrm{C}_{\mathrm{x}} \mathrm{H}_{\mathrm{y}} \mathrm{O}_{\mathrm{z}}^{+}\right)$, as shown in Fig. 3. $\mathrm{CO}_{2}^{+}(\mathrm{m} / \mathrm{z} 44)$ is the most prominent ion and contributes $25 \%$ and $16 \%$ of the signal of LV-OOA and SV-OOA, respectively. Under the conditions with negligible influence from biomass burning emissions, OOA (SV$\mathrm{OOA}+\mathrm{LV}-\mathrm{OOA}$ ) is regarded as a surrogate of SOA (Aiken et al., 2009; Jimenez et al., 2009; Zhang et al., 2007). LVOOA, representing aged secondary organic aerosols, shows higher O/C ratio (0.78) compared to SV-OOA (0.62). The $\mathrm{O} / \mathrm{C}$ ratio in $\mathrm{LV}-\mathrm{OOA}$ at the Changdao site is similar to the average $\mathrm{O} / \mathrm{C}$ value (0.73) in LV-OOA from 6 sites summarized by $\mathrm{Ng}$ et al. (2011b). The oxidation state of SV-OOA in this study is somewhat high, which lies in the higher range of $\mathrm{O} / \mathrm{C}$ ratios in SV-OOA summarized in previous field studies (Aiken et al., 2008; Jimenez et al., 2009) and is comparable to the ratio in SV-OOA obtained from airborne measurement of Mexico City outflow (DeCarlo et al., 2010).

The total OOA (LV-OOA+SV-OOA) correlates well with secondary inorganic species (sulfate + nitrate), consistent with a dominant secondary origin of OOA (Fig. 8) (Jimenez et al., 2009; Zhang et al., 2005a; Lanz et al., 2008). The regression slope of OOA with sulfate + nitrate is 0.35 , similar to the values (0.36-0.42) obtained in the Beijing area (Huang et al., 2010; Sun et al., 2010).

Diurnal cycles of LV-OOA and SV-OOA both show highest concentration peaks around 14-15 p.m. (Fig. 6a), 

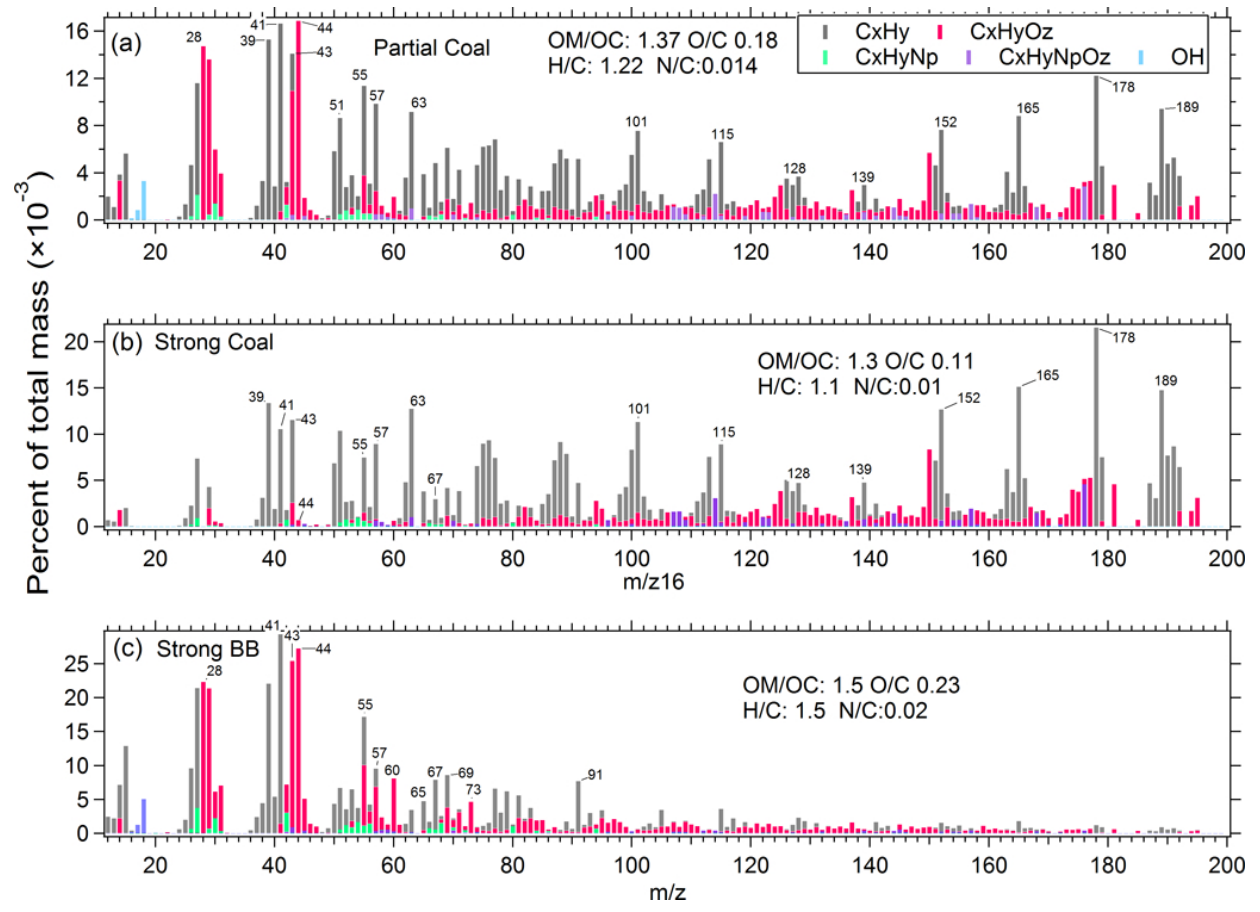

Fig. 4. High resolution mass spectra of OA in the plumes that are (a) partially-influenced by coal combustion, (b) strongly-influenced by coal combustion, (c) influenced by biomass burning emissions. The intensity of coal combustion influence is based on gas-phase naphthalene concentrations. The elemental ratios and $\mathrm{OM} / \mathrm{OC}$ ratios are also shown in the legends.

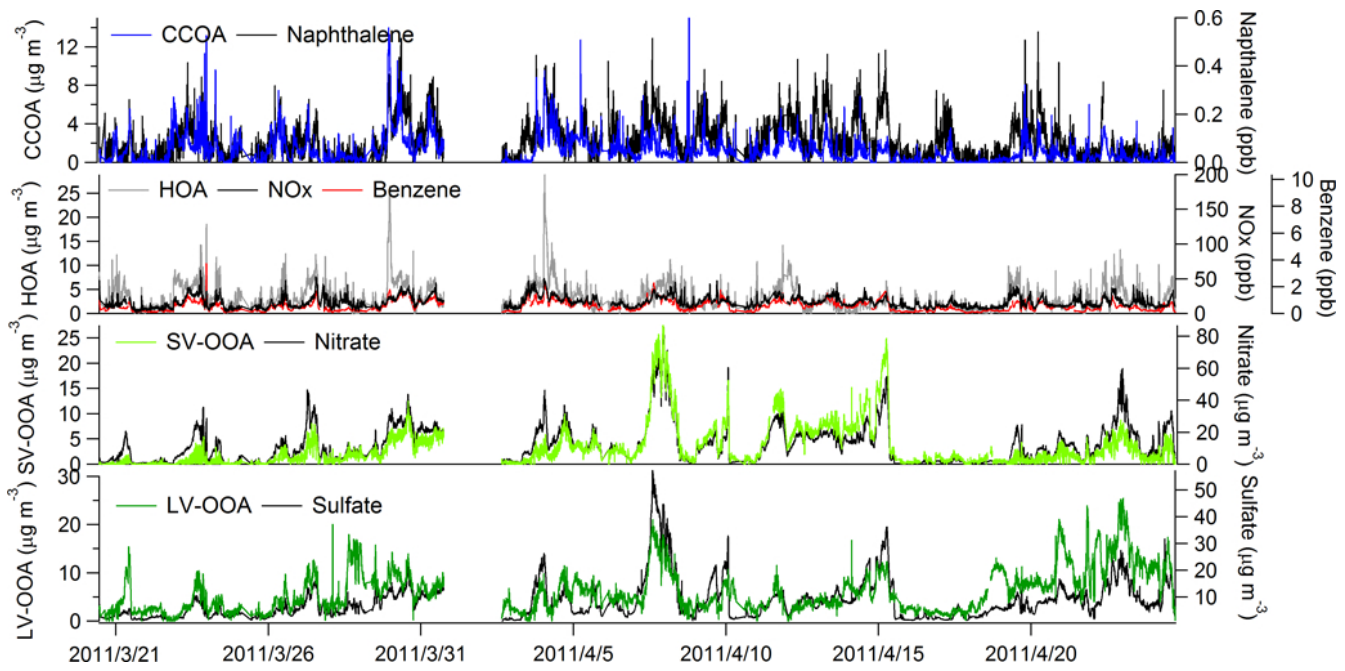

Fig. 5. Time series of OA components and external tracers (naphthalene, $\mathrm{NO}_{\mathrm{x}}$, benzene, nitrate and sulfate).

suggesting strong photochemical formation of SOA in these periods. The SV-OOA fraction of OA increases and the POA (HOA+CCOA) fraction of OA declines slightly in the afternoon (Fig. 6b), consistent with photochemical formation of SV-OOA (Jimenez et al., 2009). Larger fractions of SV-OOA in OA are observed at higher concentrations of OA (Fig. 6c). The aged SOA (LV-OOA) is present at relatively stable percentages $(\sim 30-50 \%)$ in OA. Together, LV-OOA and SV-
OOA can explain $68 \%$ of total OA masses, suggesting the importance of SOA in OA concentrations at Changdao.

The aged LV-OOA accounts for the highest contributions to the $\mathrm{C}_{\mathrm{x}} \mathrm{H}_{\mathrm{y}} \mathrm{O}_{\mathrm{z}}$ fragments (especially those fragment ions with 2 or more $\mathrm{O}$ atoms), such as $62 \%$ to $\mathrm{CO}_{2}^{+}$and $52 \%$ to $\mathrm{C}_{2} \mathrm{H}_{4} \mathrm{O}_{2}^{+}$(Fig. 7). In contrast, SV-OOA is the highest contributor to the organonitrogen $(\mathrm{ON})$ fragment ions (e.g., $\mathrm{CHNO}^{+}$ and $\mathrm{C}_{2} \mathrm{H}_{3} \mathrm{NO}^{+}$). This is consistent with the high $\mathrm{N} / \mathrm{C}$ ratio 

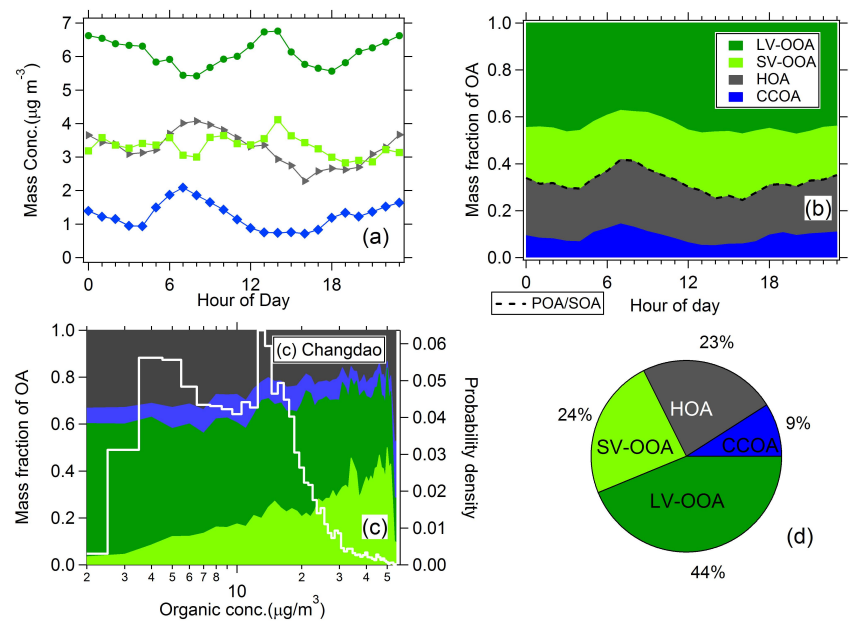

Fig. 6. Diurnal variations of concentrations and (a) fractions in OA; (b) for different OA components. (c) The fractions of different OA components in total OA as a function of concentrations of OA. (d) The average mass fraction of each OA component.

(0.041) in mass spectrum of SV-OOA. As photochemistry proceeds, SV-OOA is expected to evolve towards LV-OOA on a regional scale via processes of gas-phase oxidations of semi-volatile or heterogeneous chemistry, etc. (DeCarlo et al., 2010; Jimenez et al., 2009). A deeper analysis is presented in the next two sections.

\subsection{Elemental composition of $\mathrm{OA}$ and van Krevelen diagram}

Bulk OA at Changdao is dominated by carbon $(52 \%)$ and oxygen $(41 \%)$ with minor contributions from hydrogen $(5.8 \%)$ and nitrogen $(1.2 \%)$. Compared to reported oxygen fractions in OA $(\sim 30-35 \%)$ at other urban areas (Huang et al., 2011; Sun et al., 2011), the oxygen fraction (41\%) at the Changdao site is high.

The diurnal variations of $\mathrm{OM} / \mathrm{OC}$ and elemental ratios $(\mathrm{O} / \mathrm{C}$ and $\mathrm{H} / \mathrm{C})$ are shown in Fig. 9. The OM/OC ratio varies between 1.84 and 1.98 , while the $\mathrm{O} / \mathrm{C}$ ratio changes from 0.54 to 0.63 . The average and standard deviation of $\mathrm{OM} / \mathrm{OC}$ ratio in the whole campaign is $1.91 \pm 0.13$, which is in range of reported values (1.8-2.4) for oxygenated organic aerosols in regional or background areas (Aiken et al., 2008; Jimenez et al., 2009; Turpin and Lim, 2001). The average and standard deviation of $\mathrm{O} / \mathrm{C}$ ratio in this study is $0.59 \pm 0.10$, which lie between the range of average $\mathrm{O} / \mathrm{C}(0.4-0.7)$ of LVOOA and SV-OOA measured at other areas (DeCarlo et al., 2010; Huang et al., 2011; Jimenez et al., 2009). As shown in Fig. 9, the $\mathrm{OM} / \mathrm{OC}$ and $\mathrm{O} / \mathrm{C}$ ratios both increase rapidly after 08:00 LT and peak in the afternoon $(\sim 16: 00 \mathrm{LT})$, which may be caused by the strong photochemical formation of SOA during this period. The $\mathrm{H} / \mathrm{C}$ ratio $(1.33 \pm 0.07)$ exhibits a reverse pattern in diurnal variations of $\mathrm{OM} / \mathrm{OC}$ and $\mathrm{O} / \mathrm{C}$ ratios with a peak around 07:00-08:00 LT due to higher influence of primary emissions in a shallow boundary layer.

The van Krevelen diagram, which displays the variation of $\mathrm{O} / \mathrm{C}$ versus of $\mathrm{H} / \mathrm{C}$, can be used as a tool to probe bulk oxidation reaction mechanisms for organic aerosols (Heald et al., 2010). H/C and $\mathrm{O} / \mathrm{C}$ evolve along a line with a slope of -0.63 in the Changdao campaign. The identified reactions associated with the replacement of functional groups are also shown in Fig. 11. The evolution slope at Changdao falls between those carboxylic acid functionalization with fragmentation (slope $=-0.5$ ) and carboxylic acid functionalization without fragmentation (slope $=-1.0$ ). Note that in both cases the functionalization can also be explained by the addition of an alcohol and carbonyl group in different carbons, rather than a carboxylic acid group. The evolution slopes $(\mathrm{H} / \mathrm{C}$ versus $\mathrm{O} / \mathrm{C})$ in van Krevelen diagrams from other field and lab studies are summarized in Table 3. The results from most of field studies obtained slopes between -0.5 and -1.0 . The slope observed at Changdao $(-0.63)$ is similar to the values $(-0.64)$ obtained in Pasadena (Hayes et al., 2013).

A scatter plot of $\mathrm{H} / \mathrm{C}$ vs. O/C for PMF factors from field campaigns and sources (cooking and biomass burning) from laboratory studies are shown in Fig. 10b (He et al., 2011; Huang et al., 2010, 2011; He et al., 2010). The H/C and O/C ratios from plumes from biomass burning and coal combustion in Changdao are also shown. The results show that when $\mathrm{O} / \mathrm{C}$ ratios are higher than 0.3, the PMF resolved factors (SV-OOA and LV-OOA) evolve along a line with a slope of -0.59 , which is slightly higher than the evolution slope $(-0.50)$ obtained from the measurements at 43 sites throughout the world (Ng et al., 2011a). However, when O/C is below 0.3 with primary emissions contributing substantial OA concentration, a steeper slope of around -2.0 in Fig. $10 \mathrm{~b}$ is observed. These different slopes for high $\mathrm{O} / \mathrm{C}$ vs. low $\mathrm{O} / \mathrm{C}$ regimes have been reported in previous studies (Lambe et al., 2012; Ng et al., 2011a), which suggests that carbonyl groups addition with little fragmentation dominates the OA oxidation at low $\mathrm{O} / \mathrm{C}$ ratios, while the carboxylic acid groups addition (or alcohol+carbonyl) with significant fragmentation dominates the $\mathrm{OA}$ oxidation at high $\mathrm{O} / \mathrm{C}$ ratios. However, the steeper slope of OA evolution at the early stage of aging is not observed from the ambient measurements. The likely reason for this is the ubiquitous presence of some aged air and OOA, so that few data points in ambient data have $\mathrm{O} / \mathrm{C}$ ratios lower than 0.1 (Table 3) at both urban and rural sites. Thus, without PMF analysis the bulk ambient OA does not often display the early evolution illustrated in Fig. 10b.

It should be noted that PMF factor CCOA and ambient coal combustion plumes show lower $\mathrm{H} / \mathrm{C}$ ratios (1.1-1.4) than other POA factors (1.4-1.8) in the van Krevelen diagram. As observed in Fig. 10a, some data points diverge from the main evolution pattern as the CCOA fraction in $\mathrm{OA}$ increases, and these also tend to have lower $\mathrm{O} / \mathrm{C}$ and $\mathrm{H} / \mathrm{C}$ ratios (Fig. 10a). The evolution of OA in van Krevelen 

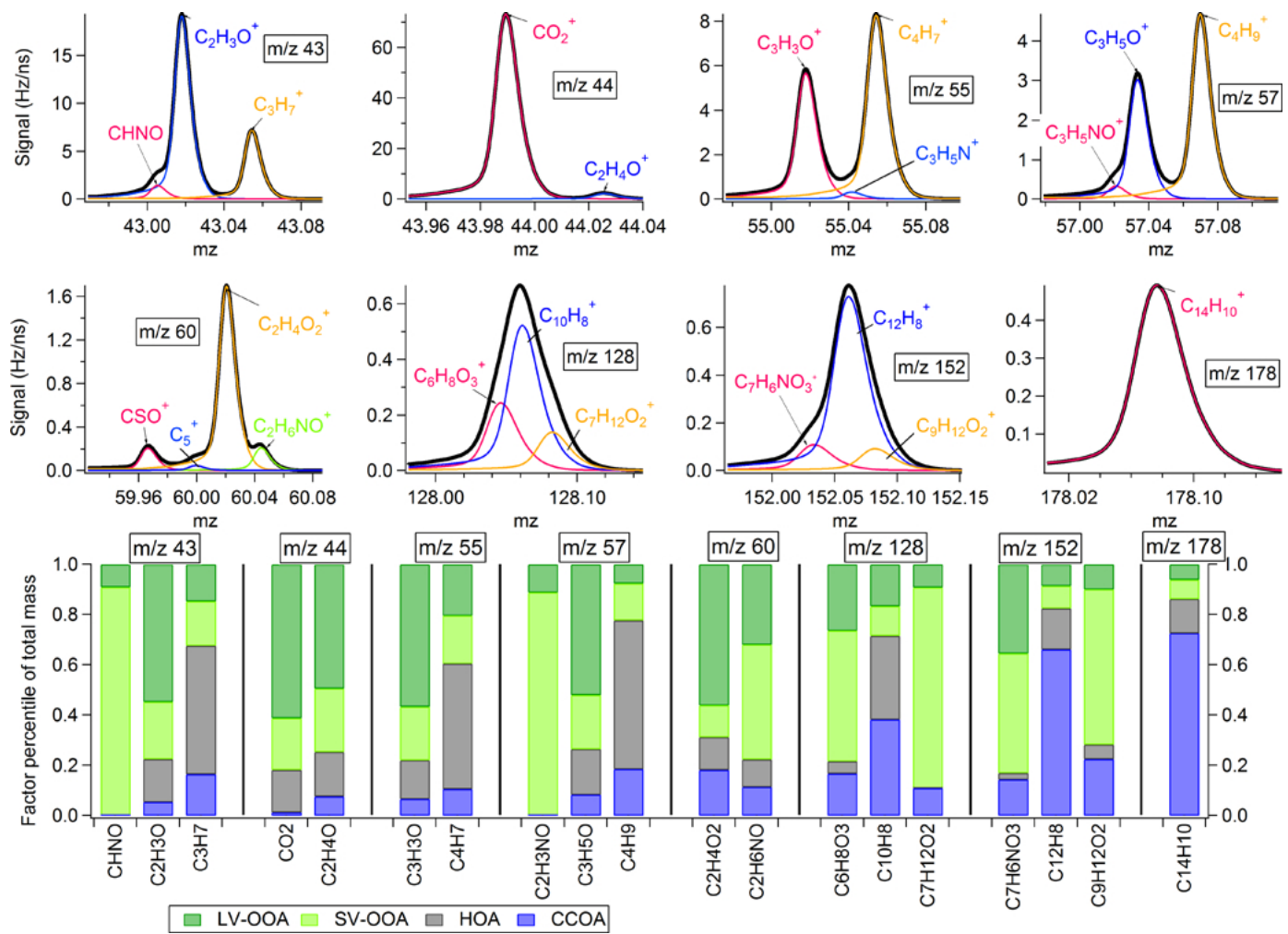

Fig. 7. High resolution ion signals for important organic fragment ions (upper graphs). The signals are shown for a specific point in time (at 20:38 LT on 7 April) with high organic concentrations as an example. Only the ions used in the PMF are shown here. The average contributions of each OA component to the specific ions are shown in the lower graphs.

Table 3. Summary of the slopes (H/C ratios vs. O/C ratios) determined from ambient and laboratory studies in the van Krevelen diagram.

\begin{tabular}{lllll}
\hline Sites & Site type* & Slope & O / C ratios range & References \\
\hline Field campaigns & & & & \\
\hline Changdao & DW & -0.63 & $0.2-0.8$ & This study \\
Kaiping & DW & -0.76 & $0.3-0.65$ & Huang et al. (2011) \\
Pasadena & DW & -0.64 & $0.2-0.8$ & Hayes et al. (2013) \\
Beijing & $\mathrm{U}$ & -0.88 & $0.1-0.5$ & Huang et al. (2010) \\
Shenzhen & $\mathrm{U}$ & -0.87 & $0.1-0.43$ & He et al. (2011) \\
Pittsburgh & $\mathrm{U}$ & -1 & $0.2-0.5$ & Heald et al. (2010) \\
Amazon & $\mathrm{F}$ & -1 & $0.15-0.65$ & Heald et al. (2010) \\
\hline Ambient PMF factors & Synthetic & $-2(\mathrm{O} / \mathrm{C}<0.3) ;$ & $0-1.2$ & Ng et al. (2011a) \\
& & $-0.5(\mathrm{O} / \mathrm{C}>0.3)$ & & \\
\hline Field and lab studies & Synthetic & -1 & $0-1.0$ & Heald et al. (2010) \\
\hline Alkane $\left(\mathrm{C}_{10} / \mathrm{C}_{15}\right)$ & Lab & $-1.3(\mathrm{O} / \mathrm{C}<0.3) ;$ & $0-1.2$ & Lambe et al. (2012) \\
& & $-0.7(\mathrm{O} / \mathrm{C}>0.3)$ & & \\
\hline JP-10 & Lab & -0.5 & $0.3-1.2$ & Lambe et al. (2012) \\
\hline
\end{tabular}

* DW: downwind site; U: urban site; F: forest site. 


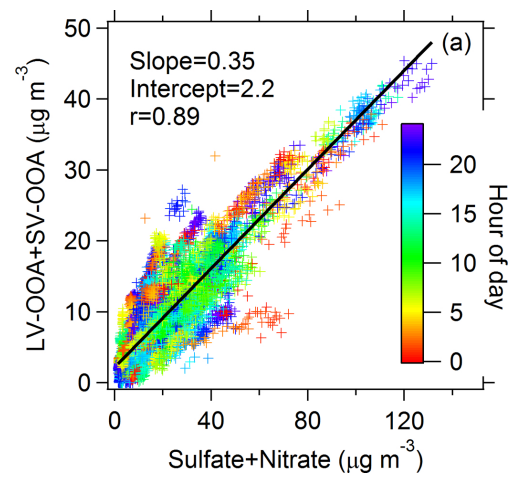

Fig. 8. The scatter plot of total OOA (LV-OOA+SV-OOA) versus secondary inorganic species (sulfate+ammonium). The data points are color-coded according to diurnal time of measurement.

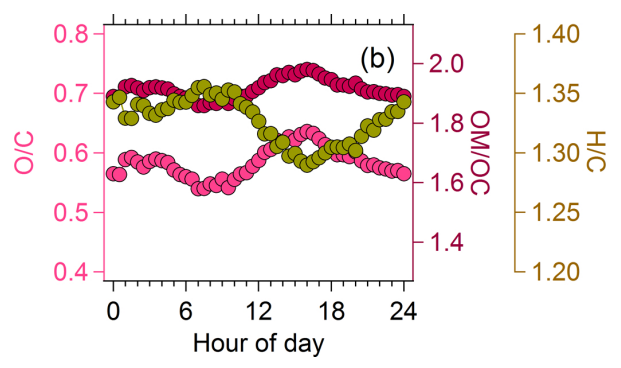

Fig. 9. Diurnal profiles of $\mathrm{OM} / \mathrm{OC}, \mathrm{O} / \mathrm{C}$ and $\mathrm{H} / \mathrm{C}$ ratios.

diagrams for the data points influenced by coal combustion are shown in Fig. 11. The periods that were excluded in PMF analysis for the strong influence of local coal combustion are also included in Fig. 11. The relative fraction of coal combustion in $\mathrm{OA}$ is represented by the fraction of $\mathrm{C}_{14} \mathrm{H}_{10}^{+}$(at $m / z 178)$ in OA. The data points with strong influence by local coal combustion have a positive slope, rather than the negative slopes for OA evolution of urban and biogenic emissions (Table 3). There are two possible reasons for the totally different evolution pattern. (1) Most likely, the physical mixing of coal combustion plumes with air containing other OA with both high $\mathrm{H} / \mathrm{C}$ and $\mathrm{O} / \mathrm{C}$ ratios would increase $\mathrm{H} / \mathrm{C}$ and $\mathrm{O} / \mathrm{C}$ ratios simultaneously along a "mixing line". High abundance of $\mathrm{m} / \mathrm{z} \mathrm{CO}_{2}^{+}$observed in the spectra influenced by coal combustion without subtracting background signals (not shown here) may be evidence of effects from physical mixing. (2) This evolution might also be partially caused by the oxidation of abundant PAH species. Figure 11 shows oxidation results of gas phase naphthalene in a lab study (Kautzman et al., 2009; Chhabra et al., 2011). An increase of O/C and $\mathrm{H} / \mathrm{C}$ ratios is observed in the oxidation of naphthalene as a result of the breakage of the ring structure in naphthalene and probably also in other PAHs species (Kautzman et al., 2009). However, the direction of evolution of naphthalene oxidation products in the van Krevelen diagram is less similar to that observed. Hence, the evolution of $\mathrm{O} / \mathrm{C}$ ver-
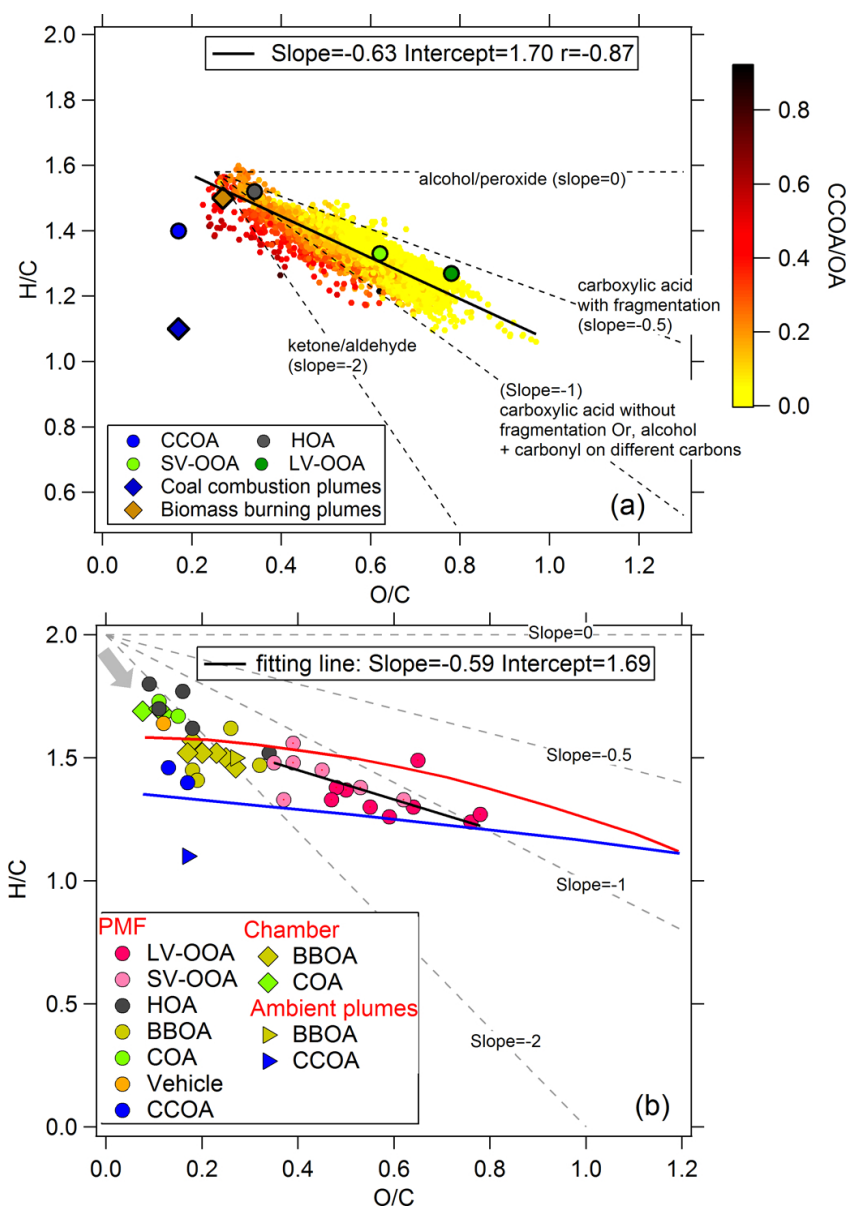

Fig. 10. (a) The van Krevelen diagram during Changdao campaign (dots). The data points are color-coded using the fractions of CCOA in OA (CCOA / OA). The values of PMF factors (circles) and plumes of coal combustion and biomass burning emissions (rhombus) are also shown. The black line is the regression results of the data points during the Changdao campaign. (b) The van Krevelen diagram of PMF factor from field campaigns in China (He et al., 2011; Huang et al., 2010, 2011, 2012). The $\mathrm{H} / \mathrm{C}$ and $\mathrm{O} / \mathrm{C}$ ratios in biomass burning and cooking emissions measured from laboratory studies (He et al., 2010) and the plumes of biomass burning and coal combustion identified in this study are also shown. The black line is the regression results of data points for SV-OOA and LV-OOA. The red and blue lines are obtained from the triangle plot of PMF factors determined from 43 sites around the world (Ng et al., 2011a). The dashed lines with different slopes $(0,-0.5,-1$ and -2$)$ are included in both graphs to guide the eye.

sus H/C for coal combustion data points in the van Krevelen diagram strongly suggest that it is dominated by physical mixing, with oxidation of PAHs species in coal combustion emissions playing a smaller role. 


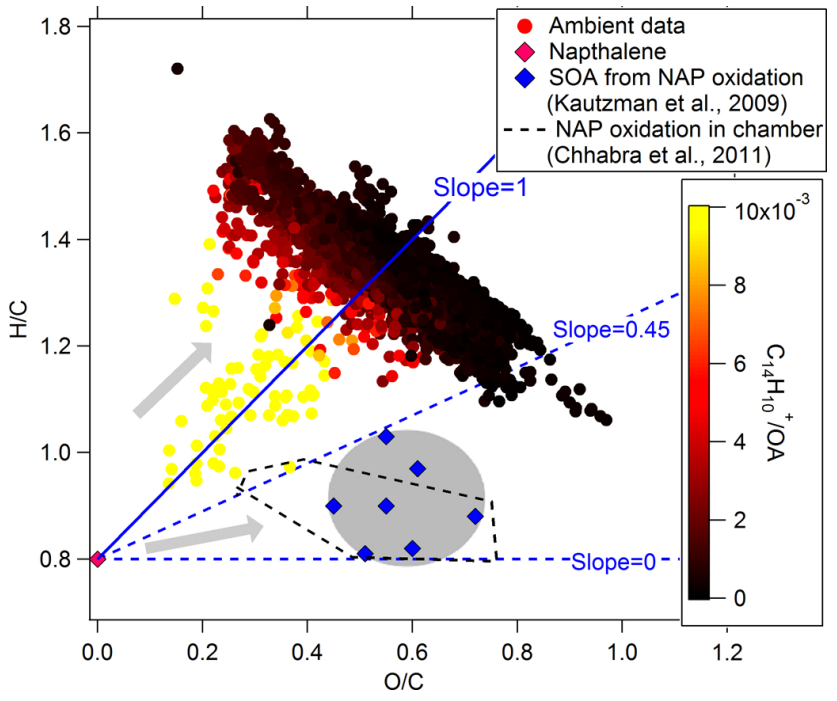

Fig. 11. The van Krevelen diagram during the Changdao campaign. The data points in the plumes influenced by local coal combustion are also included in the graph. The data points are color-coded using the fractions of $\mathrm{C}_{14} \mathrm{H}_{10}^{+}$(at $m / z$ 178) in $\mathrm{OA}$. The $\mathrm{H} / \mathrm{C}$ and $\mathrm{O} / \mathrm{C}$ ratios in the SOA from the oxidation of naphthalene obtained in chamber (blue diamonds) (Kautzman et al., 2009), as well as the $\mathrm{H} / \mathrm{C}$ and $\mathrm{O} / \mathrm{C}$ ratios of naphthalene oxidation process in another chamber study (the area in dashed black line) (Chhabra et al., 2011) are also shown. The dashed and solid blue lines with different slopes are shown to guide the eye.

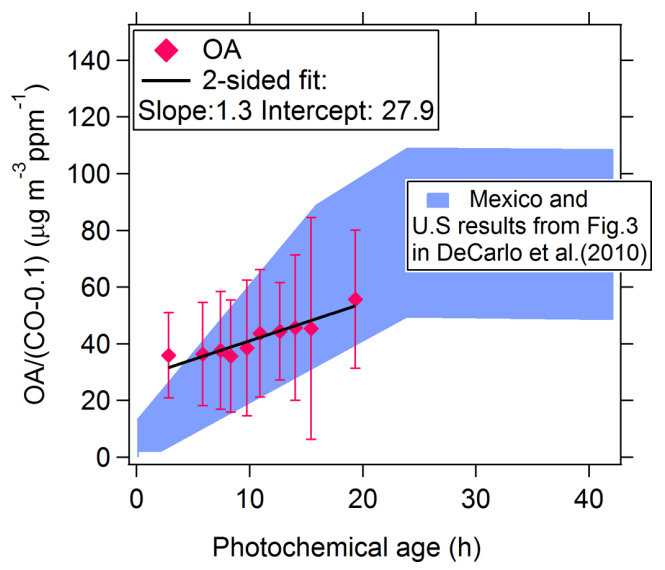

Fig. 12. OA / $\triangle \mathrm{CO}$ ratios as a function of photochemical age during the Changdao campaign. The photochemical age is classified into 10 bins by decile of photochemical age. The averages and standard deviation in each photochemical age bin are also shown (pink diamonds and bars). The purple line is the linear regression results from the average values in each photochemical bin. The blue shaded areas are the SOA formation relationship with photochemical age determined in the US and Mexico City (DeCarlo et al., 2008).

\subsection{Evolution of $\mathrm{OA} / \triangle \mathrm{CO}$ and $\mathrm{O} / \mathrm{C}$ with photochemical age}

The effects of emissions and transport of OA in the atmosphere can be better studied by normalizing OA to a combustion tracer that is relatively inert over the time scales of interest, e.g., CO (de Gouw and Jimenez, 2009). Low $\mathrm{OA} / \Delta \mathrm{CO}$ ratios (where $\Delta \mathrm{CO}$ indicates that the continental $\mathrm{CO}$ background has been subtracted) are observed in the primary emission plumes from source regions, and high $\mathrm{OA} / \triangle \mathrm{CO}$ ratios are observed after substantial SOA formation (de Gouw and Jimenez, 2009; DeCarlo et al., 2010). Plumes from biomass burning emission can also have high $\mathrm{OA} / \triangle \mathrm{CO}$ ratios, often similar or even higher than SOA / $\triangle \mathrm{CO}$ ratios from polluted air masses (Cubison et al., 2011; Jolleys et al., 2012), which complicates the use of the $\mathrm{OA} / \triangle \mathrm{CO}$ ratio in regions affected by both biomass burning and pollution emissions (Aiken et al., 2010). However, the influence of biomass burning to OA concentrations is thought to be negligible at this site after the two plumes from biomass burning emissions are excluded in PMF analysis (Part 4 of the Supplement), as confirmed by the low concentrations of both $m / z 60$ and acetonitrile during the Changdao campaign. This strongly indicates that the elevated $\mathrm{OA} / \triangle \mathrm{CO}$ ratios at Changdao can be mainly attributed to SOA formation. In our study a background concentration of $\mathrm{CO}$ of $0.1 \mathrm{ppm}$ was used based on the regression intercept between benzene and $\mathrm{CO}$ by the method of DeCarlo et al. (2010). Photochemical age was calculated using concentration ratios of $m+p$-xylene to ethylbenzene with an initial emission ratio of $2.2 \mathrm{ppb} \mathrm{ppb}^{-1}$ (de Gouw et al., 2005; Yuan et al., 2013). In order to compare with other studies (DeCarlo et al., 2010), the average $\mathrm{OH}$ radical concentration applied here is $1.6 \times 10^{6}$ molecule $\mathrm{cm}^{-3}$. A detailed description of the determination of photochemical age can be found in Yuan et al. (2013).

The estimated photochemical ages varied between 0.1 and $25 \mathrm{~h}$ and were equally divided into 10 bins according to data point number of photochemical age in ascending order of value. The box average and standard deviation of $\mathrm{OA} / \triangle \mathrm{CO}$ ratio in each bin of photochemical age are shown in Fig. 12. The average OA / $\triangle \mathrm{CO}$ ratio in each bin correlates positively with photochemical age $(r=0.9)$. The results of OA / $\Delta \mathrm{CO}$ ratios versus photochemical age in Mexico City and the northeast US summarized in DeCarlo et al. (2010) are also plotted in Fig. 12. The regression slope of average OA / $\triangle \mathrm{CO}$ versus photochemical age at Changdao was $1.3 \mu \mathrm{g} \mathrm{m}^{-3} \mathrm{~h}^{-1}$, which is lower than the ratios $\left(\sim 2-5 \mu \mathrm{g} \mathrm{m}^{-3} \mathrm{~h}^{-1}\right)$ reported in Mexico City and the US (Dzepina et al., 2009).

The average enhancement ratios of PMF factors to $\mathrm{CO}$ (PMF resolved OA/ $\triangle \mathrm{CO}$ ) in each bin as a function of photochemical age are also investigated here, as shown in Fig. 13. SOA surrogate components (LV-OOA and SV-OOA) increase and POA components (CCOA and HOA) decrease as photochemical age increases (Fig. 13a-d), which is consistent with the photochemical processing of $\mathrm{OA}$ and perhaps 

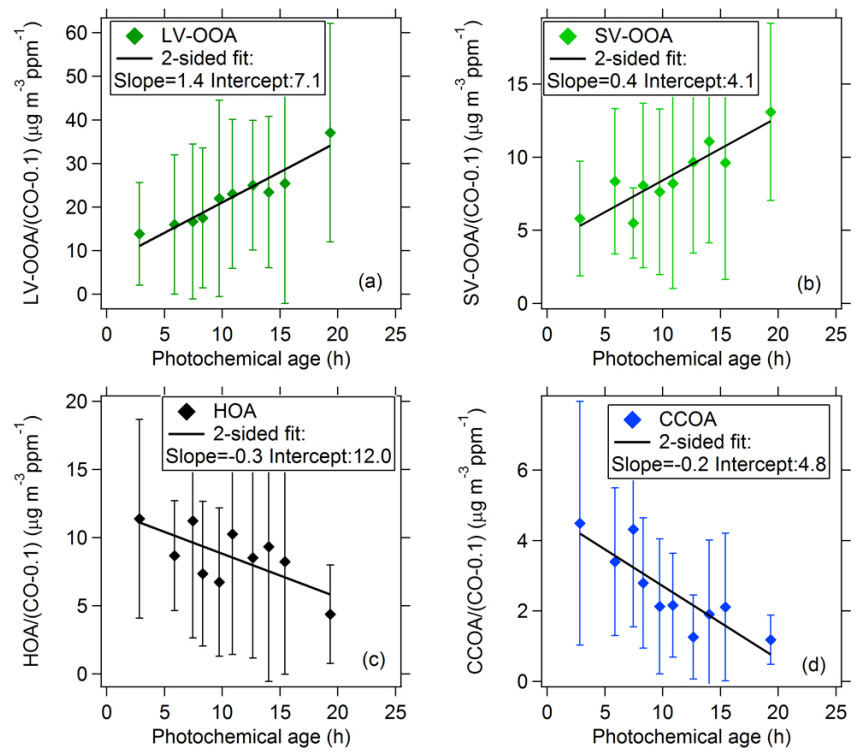

Fig. 13. The variations of (a) LV-OOA / $\Delta \mathrm{CO}$ (b) SV-OOA / $\Delta \mathrm{CO}$ (c) $\mathrm{CCOA} / \triangle \mathrm{CO}$ (d) $\mathrm{HOA} / \triangle \mathrm{CO}$ with photochemical age. The diamond points and bars are the average values and their standard deviations in each photochemical age bin. The lines are the regression results of the average values.

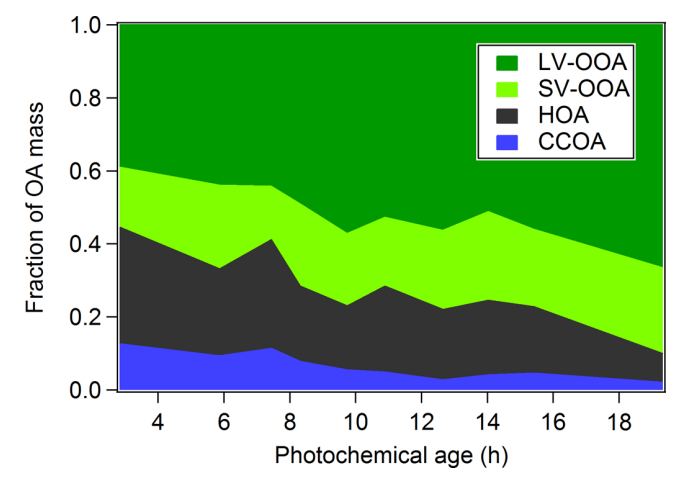

Fig. 14. Mass fraction of each OA component as a function of photochemical age.

evaporation of POA upon dilution. If we assume that reductions of $\mathrm{HOA} / \triangle \mathrm{CO}$ and $\mathrm{CCOA} / \triangle \mathrm{CO}$ ratios are due to secondary transformations (Robinson et al., 2007), the decrease of CCOA / $\triangle \mathrm{CO}$ and $\mathrm{HOA} / \triangle \mathrm{CO}$ can explain $27 \%$ of the observed LV-OOA plus SV-OOA formation. The average fractions of $\mathrm{OA}$ factors in total $\mathrm{OA}$ at each bin versus the photochemical age are calculated and shown in Fig. 14. When the photochemical age is nominally very short, POA $(\mathrm{HOA}+\mathrm{CCOA})$ accounts for $56 \%$ of total OA masses. As the photochemical age increases, the POA fraction in total OA decreases rapidly and SOA dominates OA. In the most aged plumes (photochemical age $25 \mathrm{~h}$ ), LV-OOA and SVOOA can account for $90 \%$ of total OA. The higher percentage of LV-OOA (67\%) relative to SV-OOA (23\%) in total
$\mathrm{OA}$ in the aged plumes is consistent with the interpretation that LV-OOA is more photochemically processed than SVOOA during this Changdao campaign. SV-OOA remains at a stable fraction (15-24\%) at different values of photochemical age. We note that the mixing of fresh gas-phase emissions into an air mass containing aged OA can result in low apparent photochemical ages, which may explain the substantial fraction of OOA at low apparent ages.

The evolutions of $\mathrm{OM} / \mathrm{OC}$ and $\mathrm{O} / \mathrm{C}$ vs. photochemical age are investigated in Fig. 15. Both ratios increase rapidly as photochemical age becomes longer. The $\mathrm{OM} / \mathrm{OC}$ and $\mathrm{O} / \mathrm{C}$ ratios vary over a wide range of $1.6-1.9$ and $0.3-0.6$, respectively, in air influenced by strong fresh primary plumes, which is similar to values of HOA and BBOA obtained in Mexico (Aiken et al., 2008). As the air is aged, OM / OC and $\mathrm{O} / \mathrm{C}$ ratios increase and appear to asymptote towards a maximum value. We can use the following Eq. (1) to describe data points in Fig. 15, which was adapted from a parameterization for VOC atmospheric oxidation (de Gouw et al., 2005):

$\frac{\mathrm{OM}}{\mathrm{OC}}=A-B \times \exp (C \times$ age $)$.

The fitting curves and corresponding results are shown in Fig. 15. The $A$ parameter is calculated to be 2.3 and 1.0 for the fits of $\mathrm{OM} / \mathrm{OC}$ and $\mathrm{O} / \mathrm{C}$ ratios, respectively, which are the asymptotic values for very aged plumes. The timescale of this evolution can be estimated through parameter $C$ in Eq. (1) at about $25 \mathrm{~h}$ at an average $\mathrm{OH}$ radical concentration of $1.6 \times 10^{6}$ molecule $\mathrm{cm}^{-3}$. If SOA formation and aging is represented as a first-order process proportional to $\mathrm{OH}$ (Hodzic and Jimenez, 2011; Spracklen et al., 2011), the $k_{\mathrm{OH}}$ for this study is $5.2 \times 10^{-12} \mathrm{~cm}^{3}$ molec. ${ }^{-1} \mathrm{~s}^{-1}$, which is in the range of the $k_{\mathrm{OH}}$ derived for the formation and evolution of SOA from pollution-influenced air masses in previous studies $\left(5-12.5 \times 10^{-12} \mathrm{~cm}^{3}\right.$ molec. $\left.{ }^{-1} \mathrm{~s}^{-1}\right)$ (Hodzic and Jimenez, 2011; Spracklen et al., 2011). This confirms that the timescales of SOA formation in Asian pollution appear to be similar to those in other continents.

Temperature can affect SOA formation by changing the gas/particle partition coefficient $\left(K_{\mathrm{OM}}\right)$ of VOCs oxidation products as well as reaction rates and particle water content (via RH changes), among other mechanisms. Chamber studies show that low temperatures can lead to substantial enhancements of SOA yields (Pathak et al., 2007; Takekawa et al., 2003). The scatter plots in Fig. 15 are color coded according to ambient temperatures at Changdao. The data points corresponding to higher temperatures (above $15^{\circ}$ ) tend to have lower $\mathrm{O} / \mathrm{C}$ ratios, indicating less SOA formation than at the lower temperatures, which is consistent with the chamber studies mentioned above.

\section{Conclusions}

An HR-ToF-AMS was deployed at an island of Changdao in central eastern China from March to April 2011. $\mathrm{PM}_{1}$ 

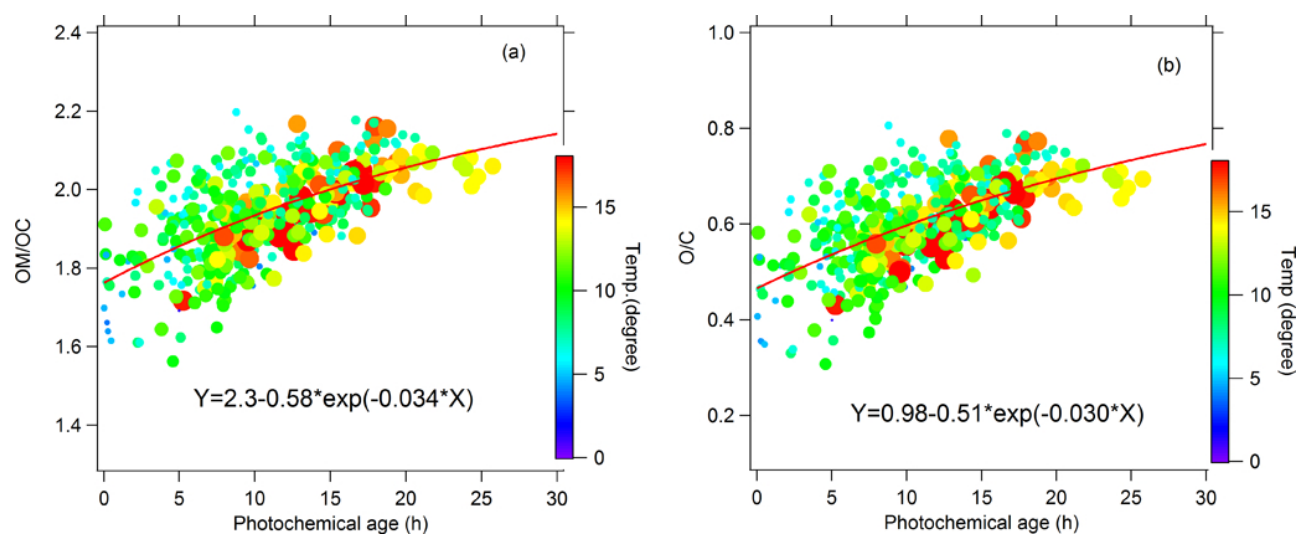

Fig. 15. (a) $\mathrm{OM} / \mathrm{OC}$ and (b) $\mathrm{O} / \mathrm{C}$ ratios vs. photochemical age. The regression was calculated by Eq. (1) in the text. The points are colorcoded according to ambient temperature.

concentrations and compositions varied strongly with transport direction of plumes. Higher $\mathrm{PM}_{1}$ concentrations were detected in the plumes originated from central eastern China and lower from the northern part of China. $\mathrm{PM}_{1}$ concentrations measured at Changdao ranged from 4.4 to $245 \mu \mathrm{g} \mathrm{m}^{-3}$, with an average value of $47 \mu \mathrm{g} \mathrm{m}^{-3}$. Organic aerosols were the most abundant $\mathrm{PM}_{1}$ components, accounting for $30 \%$ of $\mathrm{PM}_{1}$ concentrations, followed by nitrate, sulfate, ammonium, black carbon and chloride (in that order). The size distributions of inorganic aerosol (nitrate, sulfate and ammonium) showed similar shapes and had peaks at around $500-600 \mathrm{~nm}$, suggesting internally mixing of the secondary formed $\mathrm{PM}_{1}$ components. However, organic aerosols showed wider peaks at around $400-500 \mathrm{~nm}$ with enhancements at the smaller size, which could be attributed to local primary emission.

An OA component from coal combustion named CCOA was identified from the PMF analysis, which to our knowledge is reported for the first time by this study. Pronounced abundances of PAHs fragment ions in CCOA as well as average spectra influenced by local coal combustion are observed. Besides CCOA, the three components HOA, SVOOA and LV-OOA are resolved from PMF and account for $23 \%, 24 \%$ and $44 \%$ of total OA, respectively. The dominance of OOA in OA, together with the high average $\mathrm{O} / \mathrm{C}$ $(0.59)$ and OM/OC (1.98) ratios, indicates the high oxidation state of organic aerosols at Changdao. The van Krevelen diagram shows $\mathrm{H} / \mathrm{C}$ versus $\mathrm{O} / \mathrm{C}$ at Changdao evolves along a line with a slope of -0.63 . However, organic aerosols influenced by coal combustion evolve in a unique way in the van Krevelen diagram. As O/C ratio in coal combustion emissions increases, $\mathrm{H} / \mathrm{C}$ ratio increases at the same time, which is most likely due to physical mixing of coal combustion emissions with air containing other OA.

Positive correlations of $\mathrm{OA} / \triangle \mathrm{CO}$ as well as $\mathrm{LV}$ $\mathrm{OOA} / \triangle \mathrm{CO}$ and SV-OOA / $\triangle \mathrm{CO}$ versus photochemical age and negative correlations of $\mathrm{HOA} / \triangle \mathrm{CO}$ and $\mathrm{CCOA} / \triangle \mathrm{CO}$ versus photochemical age are found. LV-OOA is the dom- inant fraction in secondary formation of OA, with a maximum of $67 \%$ in the oldest plumes (photochemical age of $25 \mathrm{~h}$ ). If SOA formation and aging is represented as a firstorder process proportional to $\mathrm{OH}$, the $k_{\mathrm{OH}}$ for this study is $5.2 \times 10^{-12} \mathrm{~cm}^{3}$ molecule ${ }^{-1} \mathrm{~s}^{-1}$, calculated from the regression results of $\mathrm{O} / \mathrm{C}$ ratios and photochemical age. The apparent first-order $k_{\mathrm{OH}}$ value determined at Changdao is similar to those determined in recent studies of polluted air in other continents. To investigate the representativeness of the oxidation timescale estimated at Changdao, further studies on $k_{\mathrm{OH}}$ in other regions of China should be done. Results in this study suggest that low temperatures may favor SOA partitioning.

\section{Supplementary material related to this article is available online at http://www.atmos-chem-phys.net/13/ 10095/2013/acp-13-10095-2013-supplement.pdf.}

Acknowledgements. This work was supported by the China Ministry of Environmental Protection's Special Funds for Scientific Research on Public Welfare (201009002) and the National Natural Science Foundation of China (21025728, 21190052 and 41121004). We sincerely thank the CAPTAIN-Changdao team for their help and support for this research. We are also very grateful for Lisa Li's (University of East Anglia, UEA) English revision and suggestions, John Jayne, Edward Fortner, Bill Brook (Aerodyne Research Inc.) and Ping Chen's (Handix LLC) help on AMS instrumentations, as well as Renyi Zhang's (Texas A\&M University) valuable suggestions on paper revisions. J. L. Jimenez was supported by DOE (BER/ASR) DE-SC0006035 \& DE-FG0211ER65293.

Edited by: X. Tie 


\section{References}

Aiken, A. C., Decarlo, P. F., Kroll, J. H., Worsnop, D. R., Huffman, J. A., Docherty, K. S., Ulbrich, I. M., Mohr, C., Kimmel, J. R., Sueper, D., Sun, Y., Zhang, Q., Trimborn, A., Northway, M., Ziemann, P. J., Canagaratna, M. R., Onasch, T. B., Alfarra, M. R., Prevot, A. S. H., Dommen, J., Duplissy, J., Metzger, A., Baltensperger, U., and Jimenez, J. L.: O/C and OM/OC ratios of primary, secondary, and ambient organic aerosols with highresolution time-of-flight aerosol mass spectrometry, Environ. Sci. Technol., 42, 4478-4485, doi:10.1021/Es703009q, 2008.

Aiken, A. C., Salcedo, D., Cubison, M. J., Huffman, J. A., DeCarlo, P. F., Ulbrich, I. M., Docherty, K. S., Sueper, D., Kimmel, J. R., Worsnop, D. R., Trimborn, A., Northway, M., Stone, E. A., Schauer, J. J., Volkamer, R. M., Fortner, E., de Foy, B., Wang, J., Laskin, A., Shutthanandan, V., Zheng, J., Zhang, R., Gaffney, J., Marley, N. A., Paredes-Miranda, G., Arnott, W. P., Molina, L. T., Sosa, G., and Jimenez, J. L.: Mexico City aerosol analysis during MILAGRO using high resolution aerosol mass spectrometry at the urban supersite (T0) - Part 1: Fine particle composition and organic source apportionment, Atmos. Chem. Phys., 9, 6633-6653, doi:10.5194/acp-9-6633-2009, 2009.

Aiken, A. C., de Foy, B., Wiedinmyer, C., DeCarlo, P. F., Ulbrich, I. M., Wehrli, M. N., Szidat, S., Prevot, A. S. H., Noda, J., Wacker, L., Volkamer, R., Fortner, E., Wang, J., Laskin, A., Shutthanandan, V., Zheng, J., Zhang, R., Paredes-Miranda, G., Arnott, W. P., Molina, L. T., Sosa, G., Querol, X., and Jimenez, J. L.: Mexico city aerosol analysis during MILAGRO using high resolution aerosol mass spectrometry at the urban supersite (T0) - Part 2: Analysis of the biomass burning contribution and the nonfossil carbon fraction, Atmos. Chem. Phys., 10, 5315-5341, doi:10.5194/acp-10-5315-2010, 2010.

Allan, J. D., Williams, P. I., Morgan, W. T., Martin, C. L., Flynn, M. J., Lee, J., Nemitz, E., Phillips, G. J., Gallagher, M. W., and Coe, H.: Contributions from transport, solid fuel burning and cooking to primary organic aerosols in two UK cities, Atmos. Chem. Phys., 10, 647-668, doi:10.5194/acp-10-647-2010, 2010.

Canagaratna, M. R., Jayne, J. T., Ghertner, D. A., Herndon, S., Shi, Q., Jimenez, J. L., Silva, P. J., Williams, P., Lanni, T., Drewnick, F., Demerjian, K. L., Kolb, C. E., and Worsnop, D. R.: Chase studies of particulate emissions from in-use New York City vehicles, Aerosol Sci. Tech., 38, 555-573, doi:10.1080/02786820490465504, 2004.

Canagaratna, M. R., Jayne, J. T., Jimenez, J. L., Allan, J. D., Alfarra, M. R., Zhang, Q., Onasch, T. B., Drewnick, F., Coe, H., Middlebrook, A., Delia, A., Williams, L. R., Trimborn, A. M., Northway, M. J., DeCarlo, P. F., Kolb, C. E., Davidovits, P., and Worsnop, D. R.: Chemical and microphysical characterization of ambient aerosols with the aerodyne aerosol mass spectrometer, Mass Spectrom. Rev., 26, 185-222, doi:10.1002/Mas.20115, 2007.

Chhabra, P. S., Ng, N. L., Canagaratna, M. R., Corrigan, A. L., Russell, L. M., Worsnop, D. R., Flagan, R. C., and Seinfeld, J. H.: Elemental composition and oxidation of chamber organic aerosol, Atmos. Chem. Phys., 11, 8827-8845, doi:10.5194/acp-11-88272011, 2011.

Cubison, M. J., Ortega, A. M., Hayes, P. L., Farmer, D. K., Day, D., Lechner, M. J., Brune, W. H., Apel, E., Diskin, G. S., Fisher, J. A., Fuelberg, H. E., Hecobian, A., Knapp, D. J., Mikoviny, T., Riemer, D., Sachse, G. W., Sessions, W., Weber, R. J., Wein- heimer, A. J., Wisthaler, A., and Jimenez, J. L.: Effects of aging on organic aerosol from open biomass burning smoke in aircraft and laboratory studies, Atmos. Chem. Phys., 11, 12049-12064, doi:10.5194/acp-11-12049-2011, 2011.

DeCarlo, P. F., Kimmel, J. R., Trimborn, A., Northway, M. J., Jayne, J. T., Aiken, A. C., Gonin, M., Fuhrer, K., Horvath, T., Docherty, K. S., Worsnop, D. R., and Jimenez, J. L.: Field-deployable, high-resolution, time-of-flight aerosol mass spectrometer, Anal. Chem., 78, 8281-8289, doi:10.1021/Ac061249n, 2006.

DeCarlo, P. F., Ulbrich, I. M., Crounse, J., de Foy, B., Dunlea, E. J., Aiken, A. C., Knapp, D., Weinheimer, A. J., Campos, T., Wennberg, P. O., and Jimenez, J. L.: Investigation of the sources and processing of organic aerosol over the Central Mexican Plateau from aircraft measurements during MILAGRO, Atmos. Chem. Phys., 10, 5257-5280, doi:10.5194/acp-10-52572010, 2010.

de Gouw, J. and Jimenez, J. L.: Organic Aerosols in the Earth's Atmosphere, Environ. Sci. Technol., 43, 7614-7618, doi:10.1021/Es9006004, 2009.

de Gouw, J. A., Middlebrook, A. M., Warneke, C., Goldan, P. D., Kuster, W. C., Roberts, J. M., Fehsenfeld, F. C., Worsnop, D. R., Canagaratna, M. R., Pszenny, A. A. P., Keene, W. C., Marchewka, M., Bertman, S. B., and Bates, T. S.: Budget of organic carbon in a polluted atmosphere: Results from the New England Air Quality Study in 2002, J. Geophys. Res.-Atmos., 110, D16305, doi:10.1029/2004JD005623, 2005.

Donahue, N. M., Epstein, S. A., Pandis, S. N., and Robinson, A. L.: A two-dimensional volatility basis set: 1. organic-aerosol mixing thermodynamics, Atmos. Chem. Phys., 11, 3303-3318, doi:10.5194/acp-11-3303-2011, 2011.

Dong, H.-B., Zeng, L.-M., Hu, M., Wu, Y.-S., Zhang, Y.-H., Slanina, J., Zheng, M., Wang, Z.-F., and Jansen, R.: Technical Note: The application of an improved gas and aerosol collector for ambient air pollutants in China, Atmos. Chem. Phys., 12, 1051910533, doi:10.5194/acp-12-10519-2012, 2012.

Dzepina, K., Arey, J., Marr, L. C., Worsnop, D. R., Salcedo, D., Zhang, Q., Onasch, T. B., Molina, L. T., Molina, M. J., and Jimenez, J. L.: Detection of particle-phase polycyclic aromatic hydrocarbons in Mexico City using an aerosol mass spectrometer, Int. J. Mass. Spectrom., 263, 152-170, doi:10.1016/j.ijms.2007.01.010, 2007.

Dzepina, K., Volkamer, R. M., Madronich, S., Tulet, P., Ulbrich, I. M., Zhang, Q., Cappa, C. D., Ziemann, P. J., and Jimenez, J. L.: Evaluation of recently-proposed secondary organic aerosol models for a case study in Mexico City, Atmos. Chem. Phys., 9, 5681-5709, doi:10.5194/acp-9-5681-2009, 2009.

Dzepina, K., Jimenez, J. L., Cappa, C. D., Volkamer, R. M., Madronich, S., DeCarlo, P. F., and Zaveri, R. A.: Modeling the Multiday Evolution and Aging of Secondary Organic Aerosol During MILAGRO 2006, Environ. Sci. Technol., 45, 3496-3503, doi:10.1021/es103186f, 2011.

Ervens, B., Turpin, B. J., and Weber, R. J.: Secondary organic aerosol formation in cloud droplets and aqueous particles (aqSOA): a review of laboratory, field and model studies, Atmos. Chem. Phys., 11, 11069-11102, doi:10.5194/acp-1111069-2011, 2011.

Hallquist, M., Wenger, J. C., Baltensperger, U., Rudich, Y., Simpson, D., Claeys, M., Dommen, J., Donahue, N. M., George, C., Goldstein, A. H., Hamilton, J. F., Herrmann, H., Hoffmann, T., 
Iinuma, Y., Jang, M., Jenkin, M. E., Jimenez, J. L., KiendlerScharr, A., Maenhaut, W., McFiggans, G., Mentel, Th. F., Monod, A., Prévôt, A. S. H., Seinfeld, J. H., Surratt, J. D., Szmigielski, R., and Wildt, J.: The formation, properties and impact of secondary organic aerosol: current and emerging issues, Atmos. Chem. Phys., 9, 5155-5236, doi:10.5194/acp-9-51552009, 2009.

Hayes, P. L., Ortega, A. M., Cubison, M. J., Froyd, K. D., Zhao, Y., Cliff, S. S., Hu, W. W., Toohey, D. W., Flynn, J. H., Lefer, B. L., Grossberg, N., Alvarez, S., Rappenglück, B., Taylor, J. W., Allan, J. D., Holloway, J. S., Gilman, J. B., Kuster, W. C., de Gouw, J. A., Massoli, P., Zhang, X., Liu, J., Weber, R. J., Corrigan, A. L., Russell, L. M., Isaacman, G., Worton, D. R., Kreisberg, N. M., Goldstein, A. H., Thalman, R., Waxman, E. M., Volkamer, R., Lin, Y. H., Surratt, J. D., Kleindienst, T. E., Offenberg, J. H., Dusanter, S., Griffith, S., Stevens, P. S., Brioude, J., Angevine, W. M., and Jimenez, J. L.: Organic aerosol composition and sources in Pasadena, California, during the 2010 CalNex campaign, J. Geophys. Res.-Atmos., 118, 9233-9257, doi:10.1002/jgrd.50530, 2013.

He, L.-Y., Lin, Y., Huang, X.-F., Guo, S., Xue, L., Su, Q., Hu, M., Luan, S.-J., and Zhang, Y.-H.: Characterization of highresolution aerosol mass spectra of primary organic aerosol emissions from Chinese cooking and biomass burning, Atmos. Chem. Phys., 10, 11535-11543, doi:10.5194/acp-10-11535-2010, 2010.

He, L. Y., Huang, X. F., Xue, L., Hu, M., Lin, Y., Zheng, J., Zhang, R. Y., and Zhang, Y. H.: Submicron aerosol analysis and organic source apportionment in an urban atmosphere in Pearl River Delta of China using high-resolution aerosol mass spectrometry, J Geophys Res-Atmos, 116, 10.1029/2010JD014566, 10.1029/2010JD014566, 2011.

Heald, C. L., Kroll, J. H., Jimenez, J. L., Docherty, K. S., DeCarlo, P. F., Aiken, A. C., Chen, Q., Martin, S. T., Farmer, D. K., and Artaxo, P.: A simplified description of the evolution of organic aerosol composition in the atmosphere, Geophys. Res. Lett., 37, L08803, doi:10.1029/2010g1042737, 2010.

Heald, C. L., Coe, H., Jimenez, J. L., Weber, R. J., Bahreini, R., Middlebrook, A. M., Russell, L. M., Jolleys, M., Fu, T.-M., Allan, J. D., Bower, K. N., Capes, G., Crosier, J., Morgan, W. T., Robinson, N. H., Williams, P. I., Cubison, M. J., DeCarlo, P. F., and Dunlea, E. J.: Exploring the vertical profile of atmospheric organic aerosol: comparing 17 aircraft field campaigns with a global model, Atmos. Chem. Phys., 11, 12673-12696, doi:10.5194/acp-11-12673-2011, 2011.

Hodzic, A. and Jimenez, J. L.: Modeling anthropogenically controlled secondary organic aerosols in a megacity: a simplified framework for global and climate models, Geosci. Model Dev., 4, 901-917, doi:10.5194/gmd-4-901-2011, 2011.

Hodzic, A., Jimenez, J. L., Madronich, S., Canagaratna, M. R., DeCarlo, P. F., Kleinman, L., and Fast, J.: Modeling organic aerosols in a megacity: potential contribution of semi-volatile and intermediate volatility primary organic compounds to secondary organic aerosol formation, Atmos. Chem. Phys., 10, 5491-5514, doi:10.5194/acp-10-5491-2010, 2010.

Hu, W. W., Hu, M., Deng, Z. Q., Xiao, R., Kondo, Y., Takegawa, N., Zhao, Y. J., Guo, S., and Zhang, Y. H.: The characteristics and origins of carbonaceous aerosol at a rural site of PRD in summer of 2006, Atmos. Chem. Phys., 12, 1811-1822, doi:10.5194/acp12-1811-2012, 2012.
Huang, X.-F., He, L.-Y., Hu, M., Canagaratna, M. R., Sun, Y., Zhang, Q., Zhu, T., Xue, L., Zeng, L.-W., Liu, X.-G., Zhang, Y.-H., Jayne, J. T., Ng, N. L., and Worsnop, D. R.: Highly time-resolved chemical characterization of atmospheric submicron particles during 2008 Beijing Olympic Games using an Aerodyne High-Resolution Aerosol Mass Spectrometer, Atmos. Chem. Phys., 10, 8933-8945, doi:10.5194/acp-10-8933-2010, 2010.

Huang, X.-F., He, L.-Y., Hu, M., Canagaratna, M. R., Kroll, J. H., Ng, N. L., Zhang, Y.-H., Lin, Y., Xue, L., Sun, T.-L., Liu, X.-G., Shao, M., Jayne, J. T., and Worsnop, D. R.: Characterization of submicron aerosols at a rural site in Pearl River Delta of China using an Aerodyne High-Resolution Aerosol Mass Spectrometer, Atmos. Chem. Phys., 11, 1865-1877, doi:10.5194/acp-11-18652011, 2011.

Huang, X. F., He, L. Y., Xue, L., Sun, T. L., Zeng, L. W., Gong, Z. H., Hu, M., and Zhu, T.: Highly time-resolved chemical characterization of atmospheric fine particles during 2010 Shanghai World Expo, Atmos. Chem. Phys., 12, 4897-4907, doi:10.5194/acp-12-4897-2012, 2012.

Jacobson, M. Z.: Control of fossil-fuel particulate black carbon and organic matter, possibly the most effective method of slowing global warming, J. Geophys. Res., 107, 4410, doi:10.1029/2001jd001376, 2002.

Jimenez, J. L., Canagaratna, M. R., Donahue, N. M., Prevot, A. S. H., Zhang, Q., Kroll, J. H., DeCarlo, P. F., Allan, J. D., Coe, H., Ng, N. L., Aiken, A. C., Docherty, K. S., Ulbrich, I. M., Grieshop, A. P., Robinson, A. L., Duplissy, J., Smith, J. D., Wilson, K. R., Lanz, V. A., Hueglin, C., Sun, Y. L., Tian, J., Laaksonen, A., Raatikainen, T., Rautiainen, J., Vaattovaara, P., Ehn, M., Kulmala, M., Tomlinson, J. M., Collins, D. R., Cubison, M. J., Dunlea, E. J., Huffman, J. A., Onasch, T. B., Alfarra, M. R., Williams, P. I., Bower, K., Kondo, Y., Schneider, J., Drewnick, F., Borrmann, S., Weimer, S., Demerjian, K., Salcedo, D., Cottrell, L., Griffin, R., Takami, A., Miyoshi, T., Hatakeyama, S., Shimono, A., Sun, J. Y., Zhang, Y. M., Dzepina, K., Kimmel, J. R., Sueper, D., Jayne, J. T., Herndon, S. C., Trimborn, A. M., Williams, L. R., Wood, E. C., Middlebrook, A. M., Kolb, C. E., Baltensperger, U., and Worsnop, D. R.: Evolution of Organic Aerosols in the Atmosphere, Science, 326, 1525-1529, doi:10.1126/science.1180353, 2009.

Jolleys, M. D., Coe, H., McFiggans, G., Capes, G., Allan, J. D., Crosier, J., Williams, P. I., Allen, G., Bower, K. N., Jimenez, J. L., Russell, L. M., Grutter, M., and Baumgardner, D.: Characterizing the Aging of Biomass Burning Organic Aerosol by Use of Mixing Ratios: A Meta-analysis of Four Regions, Environ. Sci. Technol., 46, 13093-13102, doi:10.1021/es302386v, 2012.

Kautzman, K. E., Surratt, J. D., Chan, M. N., Chan, A. W. H., Hersey, S. P., Chhabra, P. S., Dalleska, N. F., Wennberg, P. O., Flagan, R. C., and Seinfeld, J. H.: Chemical Composition of Gas- and Aerosol-Phase Products from the Photooxidation of Naphthalene, J. Phys. Chem. A, 114, 913-934, doi:10.1021/jp908530s, 2009.

Lambe, A. T., Onasch, T. B., Croasdale, D. R., Wright, J. P., Martin, A. T., Franklin, J. P., Massoli, P., Kroll, J. H., Canagaratna, M. R., Brune, W. H., Worsnop, D. R., and Davidovits, P.: Transitions from Functionalization to Fragmentation Reactions of Laboratory Secondary Organic Aerosol (SOA) Generated from the 
OH Oxidation of Alkane Precursors, Environ. Sci. Technol., 46, 5430-5437, doi:10.1021/es300274t, 2012.

Lanz, V. A., Alfarra, M. R., Baltensperger, U., Buchmann, B., Hueglin, C., Szidat, S., Wehrli, M. N., Wacker, L., Weimer, S., Caseiro, A., Puxbaum, H., and Prevot, A. S. H.: Source Attribution of Submicron Organic Aerosols during Wintertime Inversions by Advanced Factor Analysis of Aerosol Mass Spectra, Environ. Sci. Technol., 42, 214-220, doi:10.1021/es0707207, 2008.

Middlebrook, A. M., Bahreini, R., Jimenez, J. L., and Canagaratna, M. R.: Evaluation of Composition-Dependent Collection Efficiencies for the Aerodyne Aerosol Mass Spectrometer using Field Data, Aerosol. Sci. Tech., 46, 258-271, doi:10.1080/02786826.2011.620041, 2011.

Ng, N. L., Chhabra, P. S., Chan, A. W. H., Surratt, J. D., Kroll, J. H., Kwan, A. J., McCabe, D. C., Wennberg, P. O., Sorooshian, A., Murphy, S. M., Dalleska, N. F., Flagan, R. C., and Seinfeld, J. H.: Effect of $\mathrm{NO}_{\mathrm{x}}$ level on secondary organic aerosol (SOA) formation from the photooxidation of terpenes, Atmos. Chem. Phys., 7, 5159-5174, doi:10.5194/acp-7-5159-2007, 2007.

Ng, N. L., Canagaratna, M. R., Jimenez, J. L., Chhabra, P. S., Seinfeld, J. H., and Worsnop, D. R.: Changes in organic aerosol composition with aging inferred from aerosol mass spectra, Atmos. Chem. Phys., 11, 6465-6474, doi:10.5194/acp-11-64652011, 2011a.

Ng, N. L., Canagaratna, M. R., Jimenez, J. L., Zhang, Q., Ulbrich, I. M., and Worsnop, D. R.: Real-Time Methods for Estimating Organic Component Mass Concentrations from Aerosol Mass Spectrometer Data, Environ. Sci. Technol., 45, 910-916, doi:10.1021/es102951k, 2011b.

Pathak, R. K., Stanier, C. O., Donahue, N. M., and Pandis, S. N.: Ozonolysis of $\alpha$-pinene at atmospherically relevant concentrations: Temperature dependence of aerosol mass fractions (yields), J. Geophys. Res., 112, D03201, doi:10.1029/2006jd007436, 2007.

Poulain, L., Iinuma, Y., Müller, K., Birmili, W., Weinhold, K., Brüggemann, E., Gnauk, T., Hausmann, A., Löschau, G., Wiedensohler, A., and Herrmann, H.: Diurnal variations of ambient particulate wood burning emissions and their contribution to the concentration of Polycyclic Aromatic Hydrocarbons (PAHs) in Seiffen, Germany, Atmos. Chem. Phys., 11, 12697-12713, doi:10.5194/acp-11-12697-2011, 2011.

Robinson, A. L., Donahue, N. M., Shrivastava, M. K., Weitkamp, E. A., Sage, A. M., Grieshop, A. P., Lane, T. E., Pierce, J. R., and Pandis, S. N.: Rethinking organic aerosols: Semivolatile emissions and photochemical aging, Science, 315, 1259-1262, doi:10.1126/science.1133061, 2007.

Spracklen, D. V., Jimenez, J. L., Carslaw, K. S., Worsnop, D. R., Evans, M. J., Mann, G. W., Zhang, Q., Canagaratna, M. R., Allan, J., Coe, H., McFiggans, G., Rap, A., and Forster, P.: Aerosol mass spectrometer constraint on the global secondary organic aerosol budget, Atmos. Chem. Phys., 11, 12109-12136, doi:10.5194/acp-11-12109-2011, 2011.

Sun, J. Y., Zhang, Q., Canagaratna, M. R., Zhang, Y. M., Ng, N. L., Sun, Y. L., Jayne, J. T., Zhang, X. C., Zhang, X. Y., and Worsnop, D. R.: Highly time- and size-resolved characterization of submicron aerosol particles in Beijing using an Aerodyne Aerosol Mass Spectrometer, Atmos. Environ., 44, 131-140, doi:10.1016/j.atmosenv.2009.03.020, 2010.
Sun, Y.-L., Zhang, Q., Schwab, J. J., Demerjian, K. L., Chen, W.N., Bae, M.-S., Hung, H.-M., Hogrefe, O., Frank, B., Rattigan, O. V., and Lin, Y.-C.: Characterization of the sources and processes of organic and inorganic aerosols in New York city with a high-resolution time-of-flight aerosol mass apectrometer, Atmos. Chem. Phys., 11, 1581-1602, doi:10.5194/acp-11-15812011, 2011.

Takekawa, H., Minoura, H., and Yamazaki, S.: Temperature dependence of secondary organic aerosol formation by photooxidation of hydrocarbons, Atmos. Environ., 37, 3413-3424, doi:10.1016/s1352-2310(03)00359-5, 2003.

Turpin, B. J. and Lim, H. J.: Species contributions to $\mathrm{PM}_{2.5}$ mass concentrations: Revisiting common assumptions for estimating organic mass, Aerosol Sci. Tech., 35, 602-610, 2001.

Ulbrich, I. M., Canagaratna, M. R., Zhang, Q., Worsnop, D. R., and Jimenez, J. L.: Interpretation of organic components from Positive Matrix Factorization of aerosol mass spectrometric data, Atmos. Chem. Phys., 9, 2891-2918, doi:10.5194/acp-9-2891-2009, 2009.

Velders, G. J. M., Granier, C., Portmann, R. W., Pfeilsticker, K., Wenig, M., Wagner, T., Platt, U., Richter, A., and Burrows, J. P.: Global tropospheric $\mathrm{NO}_{2}$ column distributions: Comparing three-dimensional model calculations with GOME measurements, J. Geophys. Res.-Atmos., 106, 12643-12660, 2001.

Volkamer, R., Jimenez, J. L., San Martini, F., Dzepina, K., Zhang, Q., Salcedo, D., Molina, L. T., Worsnop, D. R., and Molina, M. J.: Secondary organic aerosol formation from anthropogenic air pollution: Rapid and higher than expected, Geophys. Res. Lett., 33, L17811, doi:10.1029/2006g1026899, 2006.

Volkamer, R., Martini, F. S., Molina, L. T., Salcedo, D., Jimenez, J. L., and Molina, M. J.: A missing sink for gas-phase glyoxal in Mexico City: Formation of secondary organic aerosol, Geophys. Res. Lett., 34, L19807, doi:10.1029/2007g1030752, 2007.

Wang, Q., Shao, M., Zhang, Y., Wei, Y., Hu, M., and Guo, S.: Source apportionment of fine organic aerosols in Beijing, Atmos. Chem. Phys., 9, 8573-8585, doi:10.5194/acp-9-8573-2009, 2009.

Weimer, S., Alfarra, M. R., Schreiber, D., Mohr, M., Prévôt, A. S. H., and Baltensperger, U.: Organic aerosol mass spectral signatures from wood-burning emissions: Influence of burning conditions and wood type, J. Geophys. Res., 113, D10304, doi:10.1029/2007JD009309, 2008.

Xiao, R., Takegawa, N., Zheng, M., Kondo, Y., Miyazaki, Y., Miyakawa, T., Hu, M., Shao, M., Zeng, L., Gong, Y., Lu, K., Deng, Z., Zhao, Y., and Zhang, Y. H.: Characterization and source apportionment of submicron aerosol with aerosol mass spectrometer during the PRIDE-PRD 2006 campaign, Atmos. Chem. Phys., 11, 6911-6929, doi:10.5194/acp-11-6911-2011, 2011.

Yuan, B., Liu, Y., Shao, M., Lu, S., and Streets, D. G.: Biomass Burning Contributions to Ambient VOCs Species at a Receptor Site in the Pearl River Delta (PRD), China, Environ. Sci. Technol., 44, 4577-4582, doi:10.1021/es1003389, 2010.

Yuan, B., Hu, W. W., Shao, M., Wang, M., Chen, W. T., Lu, S. H., Zeng, L. M., and Hu, M.: VOC emissions, evolutions and contributions to SOA formation at a receptor site in eastern China, Atmos. Chem. Phys., 13, 8815-8832, doi:10.5194/acp-13-88152013, 2013.

Zhang, Q., Alfarra, M. R., Worsnop, D. R., Allan, J. D., Coe, H., Canagaratna, M. R., and Jimenez, J. L.: Deconvolution 
and quantification of hydrocarbon-like and oxygenated organic aerosols based on aerosol mass spectrometry, Environ. Sci. Technol., 39, 4938-4952, doi:10.1021/Es0485681, 2005a.

Zhang, Q., Canagaratna, M. R., Jayne, J. T., Worsnop, D. R., and Jimenez, J. L.: Time- and size-resolved chemical composition of submicron particles in Pittsburgh: Implications for aerosol sources and processes, J. Geophys. Res.-Atmos., 110, D07s09, doi:10.1029/2004jd004649, 2005b.

Zhang, Q., Jimenez, J. L., Canagaratna, M. R., Allan, J. D., Coe, H., Ulbrich, I., Alfarra, M. R., Takami, A., Middlebrook, A. M., Sun, Y. L., Dzepina, K., Dunlea, E., Docherty, K., DeCarlo, P. F., Salcedo, D., Onasch, T., Jayne, J. T., Miyoshi, T., Shimono, A., Hatakeyama, S., Takegawa, N., Kondo, Y., Schneider, J., Drewnick, F., Borrmann, S., Weimer, S., Demerjian, K., Williams, P., Bower, K., Bahreini, R., Cottrell, L., Griffin, R. J., Rautiainen, J., Sun, J. Y., Zhang, Y. M., and Worsnop, D. R.: Ubiquity and dominance of oxygenated species in organic aerosols in anthropogenically-influenced Northern Hemisphere midlatitudes, Geophys. Res. Lett., 34, L13801, doi:10.1029/2007g1029979, 2007.
Zhang, Q., Jimenez, J., Canagaratna, M., Ulbrich, I., Ng, N., Worsnop, D., and Sun, Y.: Understanding atmospheric organic aerosols via factor analysis of aerosol mass spectrometry: a review, Anal. Bioanal. Chem., 401, 3045-3067, doi:10.1007/s00216-011-5355-y, 2011.

Zhang, Y. X., Schauer, J. J., Zhang, Y. H., Zeng, L. M., Wei, Y. J., Liu, Y., and Shao, M.: Characteristics of particulate carbon emissions from real-world Chinese coal combustion, Environ. Sci. Technol., 42, 5068-5073, doi:10.1021/Es7022576, 2008. 